\title{
The Aesthetic Contingency of Life
}

\author{
An Account of the Finite in the Time of Images
}

\author{
Isabella Guanzini
}

\section{The Gaze of the Other}

In the painting "The Ambassadors" (1533) the artist Hans Holbein the Younger makes a conscious use of anamorphosis, and testifies through his perfect technique that it is not always the direct, frontal, and sovereign perspective on things that encompasses significant details.

Sometimes it is necessary to change one's perspective and to decenter one's gaze in order to perceive what transcends what one sees, but is nevertheless what is essential. The portrait of the two young ambassadors, a politician and a churchman, depicted at the height of their power, highlights their pompous clothing in a symbolic manner. Offered a view from the side at a certain distance, the observer suddenly experiences a memento mori materializing in a skull. The skull, when viewed from the front, initially appeared as a deformed object that disturbs the elegant scenery. If one moves to the side, it does not fail to surprise by presenting itself as an identifiable shape.

Because of a sophisticated optical distortion, the anamorphic stain reveals a profiled symbology of vanitas, a call to death awaiting everyone. ${ }^{1}$ In this painting, as well as in the works of Alfred Kubin and Edward Munch, there is a snare that captivates the observer, forcing him in a way to look down. The anamorphic skull initially appears as an undifferentiated and uncanny "thing" that stains the majestic representation of temporal and spiritual power over the world. By means of a displacement, a change in the visual field, death appears as that which deactivates every rule and pales every sovereign attitude, by disrupting the illusion of worldly self-fulfillment. In this displacement, it is the image itself that "observes", and the observer suddenly finds himself observed.

In Seminar XI (The Four Fundamental Concepts of Psychoanalysis) Jacques Lacan makes reference to anamorphosis as an exemplary structure that indicates a shift in the gaze necessary in psychoanalysis for an apprehension of the desire of the subject. ${ }^{2}$ Lacan shows that the "thing," or that which is at the

1 See. J. Baltrušaitis, Anamorphoses, ou Magic artificielle des effets merveilleux, Paris 1969, 146.

2 J. Lacan, The Seminar. Book XI. The Four Fundamental Concepts of Psychoanalysis, New York/London 2009, 85-9o. 
center of desire, always presents itself in an anamorphic form, because it does not tolerate a direct encounter.

"The Ambassadors" designates a picture in which the painted object seems to observe the viewer. It dominates the scene with its mystery, giving the subject a sign of what is both hidden and visible. In his analysis, Lacan illuminates the fact that the meaning of reality can never be totalized and that there never is an all-encompassing gaze. There is always a remainder, a necessary shift that shields the ideal from any kind of direct access:

\begin{abstract}
All this shows that at the very heart of the period in which the subject emerged and geometral optics was an object of research, Holbein makes visible for us here something that is simply the subject as annihilated - annihilated in the form that is, strictly speaking, the imaged embodiment of the minus-phi $[(-\varphi)]$ of castration, which for us, centers the whole organization of the desires through the framework of the fundamental drives. ${ }^{3}$
\end{abstract}

The anamorphosis thus reveals that the subject is missing, displaced, obstructed, always permeated by the field of the Other. One can state that the gaze is the place of the Other. It is the lost object that is always displaced with respect to the perspective that sees him. It affords an understanding without ever being caught - like the oracle of Delphi in the definition of Heraclitus: "The Lord Apollo at Delphi neither reveals nor conceals, but it gives a sign." ${ }^{\prime 4}$ The gaze, in fact, is never reflective, but it is that which is always absent in the contemplation of that for which it is impossible to form an image ${ }^{5}$ :

The gaze is presented to us only in the form of a strange contingency, symbolic of what we find on the horizon, as the thrust of our experience, namely, the lack that constitutes castration anxiety. The eye and the gaze - this is for us the split in which the drive is manifested at the level of the scopic field. ${ }^{6}$

3 Ibid., 88 et seq [English translation, New York/London 2009]. According to Lacan, life is humanized only by the law of castration, which imposes the loss of part of jouissance (weaning, intrusion of the third - the father). The humanization of life happens only in the encounter with symbolic law, insofar as this law, by denying incestuous jouissance as impossible, introduces into the subject a defect that first forms the subject as subject. The power of Oedipus concerns the separation of the subject from its merging enjoyment, marked by a destructive pursuit of totality. With minus-phi (-f), Lacan refers to the fact that the image of one's own body never appears as a totality or always with a defect.

4 H. Diels, The Fragments of the Presocratics, 3 volumes, Hildesheim 2004, 1, DK 93.

5 Because of this motif Lacan adds to the Freudian instincts also the show scopic and the invocation invocatory drive, respectively the view gaze and the voice.

6 Lacan, The Seminar. Book XI, 72 et seq. 
According to Gérard Wajcman, the medieval man remained inscribed in the Other's field of vision, namely in the creation and in the protection of the eyes of God. Before one saw, one was seen, one was the object of the Other's gaze. ${ }^{7}$ The "Big Other" is this symbolic dimension that can be personified or reified, as God or as the idea to which I am attached (freedom, law, peace, communism, nation). It is the symbolic substance of our lives, not only of the explicit symbolic rules that regulate our social coexistence, but also the complex web of unwritten implicit rules that determines our speech and action.

Despite its fundamental power, the Big Other is fragile, insubstantial, virtual in the sense that its status is that of a subjective subordination. In his seminar on The Purloined Letter ${ }^{8}$, Lacan claims that a letter always reaches its destination, even if it is not sent. It can even be said that it is only the letter that is not sent that reaches its destination entirely. The true addressee is not a real person, but the Big Other Himself.

The same applies to the symptom. The addressee of my symptom is not another human being but the virtual Big Other. Social life is characterized by various unlettered rules and prohibitions, even if these rules are not explicitly stated. Nonetheless, the impact of the Big Other on everyday action and thinking is strong. When the subjects interact, they not only relate to one other, but always also to the virtual Big Other as well.

Modernity breaks across this medieval horizon by disclosing an ever more intimate private living space. The subject secures itself as subject through an unequivocal gaze that dominates the world, which it perceives from a safe distance, starting from a hidden place that lies beyond the gaze of the Other. It is not seen; it sees. The cogito ergo sum means that I exist to the extent that I am not seen, namely, to the extent that the center of gravity of my being is withdrawn into a private space that I feel is beyond the public gaze of the

7 G. Wajcman, The Birth of Intimacy, in: Lacanian Ink 23, New York 2004. "This is the gaze for which the ancient Romans carved the details in the reliefs at the top of their viaducts, details invisible to the eye of any human standing below; the gaze for which the ancient Incas made their gigantic drawings out of stones who- se form could be perceived only from high up in the air; the gaze for which the Stalinists organized their gigantic public spectacles. To specify this gaze as 'divine' is already to 'gentrify' its status, to obfuscate the fact that it is the gaze of no one, a gaze freely floating around, with no bearer ... we are originally not observers of the play-stage of reality, but part of the tableau staged for the void of a nonexisting gaze, and it is only in a secondary time that we can assume the position of those who look at the stage. The unbearable 'impossible' position is not that of the actor, but that of the observer, of the public" (Cfr: S. Žižek, Neighbors and Other Monsters, in: S. Žižek / E.L. Santner / K. Reinhard [ed.], The Neighbor: Three Inquiries in Political Theology, Chicago 2005, 178).

8 J. Lacan, Écrits. The First Complete Edition in English, New York/London 2005, 6-48. 
Other. The "birth of intimacy" increasingly closes the "third gaze" onto the individual and the collective.

The symbolic order, the structure of being in communion and having respect for the relationships that determine our common life together, as well as for the social project as a whole, is finally exhausted. As Weber said, we are now living in an epoch of disenchantment. ${ }^{9}$ The fragmentation and evaporation of transcendence has generated pluralities and differences while multiplying forms of knowledge, so that today collective subjectivity no longer entails meaningful co-living with one another.

Common belief in a transcendent reality had the power to structure reality by means of a unifying code, to enliven the social body and to regulate social exchange. Subjectivities of the twentieth century are driven by what the French philosopher Alain Badiou defines as the "Passion of the Real" (passion $d u$ réel), that is, the will to directly stabilize one's relationship with the world without mediation and protection. ${ }^{10}$ In contrast with nineteenth century visions of utopia, ideologies, and anticipations of the future, "the twentieth century aimed at delivering the thing itself, at directly realizing the longed-for New Order"."1

That is a decisive change in the gaze and in the direction of action. The "tree of life", already dislocated in its origins and reachable only in an "anamorphic" way, is now placed at the center of the garden. It was initially unattainable to the human gaze and thus the possibility of becoming an "available object" was foreclosed. That distance served as a protective shell, sheltering the human race. ${ }^{12}$ In the time of disenchantment, this "gown of grace" is removed so that reality becomes available to the will to control and the power of the acting

"Thus, increasing intellectualization and rationalization does not mean increasing general knowledge of the conditions under which we live our lives. It means something else. It means the knowledge or belief that if we only wanted to we could learn at any time that there are, in principle, no mysterious unpredictable forces in play, but that all things - in principle - can be controlled through calculation. This, however, means the disenchantment of the world. No longer, like the savage, who believed that such forces existed, do we have to re-sort to magical means to gain control over or pray to the spirits. Technical means and calculation work for us instead. This, above all, is what intellectualization actually means." (M. Weber, Science as a Vocation, in: J. Dreijmanis (ed.), Max Weber's Complete Writings on Academic and Political Vocations, New York 2008, 35).

10 See A. Badiou, The Century, Cambridge 2007.

11 S. Žižek, The Puppet and the Dwarf. The Perverse Core of Christianity, Cambridge (MA) 2003, 63 .

12 K. Appel, Christianity and a New Humanism. Historical-Theoretical and Theological Reflections on the Bible, Hegel, and Musil. First Transition - From World Time to the Feast and Death, B. The Gown of Grace and the Nakedness of Existence, 5-11. 
subject. In this way it becomes a surface of projections and an expansion of the ego:

In the extent to which the tree now comes into the center and becomes part of man, in other words, at the moment when man begins to transform the open garden into a delimited horizon of his own desire, he begins to locate his self in the sense of a narcissistic projection..$^{13}$

Slowly, the modern and postmodern subject evolves into a direct observer, a beneficiary and consumer of a world of available things. While the first was associated with a sense of guilt, in the second, the post-political subject of consumer society is exposed to a chronic sense of inadequacy that defines the psychology of our meritocracy.

In Civilization and its Discontents (1930) Freud uncovered the tension between the individual and civilization, which lies in the excess of inhibition and sublimation of impulses in the name of order and the security of society. Such a limitation of instinctual life, necessary for a dignified human life together, necessarily produced neurotic tendencies to the extent that the subject, in the name of the reality principle, was massively called upon to sublimate the pleasure principle.

In the present set-up, the psychic situation of individuals is reversed. If the previous century was characterized by the setting of boundaries (Gödel, Freud, Marx, etc.), then the new century is that of eliminating them. In the name of the right of infinite enjoyment, there seems to be nothing left that is impossible. With this conception of progression, we open ourselves to the dimension of the post-human, where the ultimate fulfillment of the individual, thanks to science, does not take place in a social, but in a purely biological realm (no suffering, no aging and no dying thanks to the technology and the different hybridization of our organism, seeing their own needs met regardless of gender, age, social status).

In the footsteps of Jacques Lacan, Massimo Recalcati says that in our hypermodern contemporaneity the "discourse of the capitalist" has played a dominant role, promoting a continuous and creeping delusion exposing the individual to the greatest risk of its subjectivity, namely the eradication of the subject of the unconscious. ${ }^{14}$ Today's omnipresent exhibition of intimacy, along with the search for the "true" ego, has supplanted the site of the unconscious, leaving the subject to the arbitrariness of its inclinations.

\footnotetext{
13 Ibid., 8.

14 M. Recalcati, L'uomo senza inconscio. Figure della nuova clinica psicoanalitica, Milano 2010.
} 
The celebration of the intimacy of the "self" is claimed to be a genuine site of truth. In the Encyclopedia of Philosophical Sciences, Hegel states that the plant is an animal that has its innards outside its body in the form of roots or flowers. ${ }^{15}$ By analogy, one could say that the decentralized symbolic order make up the mental innards of the human animal. The symbolic substance of my being, the roots from which the ego draws its spiritual nourishment, are external to the ego. The impossible dream of the New Age is precisely the transformation of humanity into a spiritual animal, which, detached from its body, wavers in an immaterial space, without needing substantial roots or alterity.

\section{The Dialectic of Desire}

Right from the beginning, the illusion of narcissistic independence and an uprooted solipsistic identity is the center of Lacan's thinking, also as a reaction and resistance to the psychology and psychoanalysis of his time. His return to Freud, especially in his first seminars, is to be understood as a resumption of the agenda of Freud's essay On Narcissism. ${ }^{16}$

As Recalcati writes, Lacan's teaching opens as "a profound reflection on the gesture of Narcissus". ${ }^{17}$ Lacan interpreted the psychoanalysis subsequent to Freud as a history of decline, because the genuine intentions of its founder were buried or misunderstood. Lacan considers ego-psychology ${ }^{18}$ with its theory of the autonomous ego as a kind of constriction and disparagement ${ }^{19}$, which aims at the development of the potentials of the subject and sees itself as an orthopedics and self-realization of the ego. According to Lacan, however, it can never be the goal of psychoanalysis to "strengthen the ego."

In his opinion, the ego is rather a construction of the imaginary, a crystallization or internalization of self-images as well as of images of one's own body, which are projected back by others on an individual. These imaginary relationships produce identifications (love) and rivalries (hate, envy) insofar

15 G.W.F. Hegel, Encyclopedia of Philosophical Sciences in Fundamentals, § 348.

16 See S. Freud, On Narcissism. The Standard Edition of the Complete Psychological Works of Sigmund Freud, Volume XIV (1914-1916): On the History of the Psycho-Analytic Movement, Papers on Metapsychology and Other Works, 67-102, London 1957.

17 M. Recalcati, Jacques Lacan. Desiderio, godimento e soggettivazione, Milano 2012, 10.

18 Ego-psychology is a psychological theory that complements classical Freudian psychoanalysis with aspects of ego development, defense mechanisms, and the functions of the ego. The founders of first-person psychology often named are A. Freud (The Self and the Defense Mechanisms, Vienna 1936) and in particular H. Hartmann (Ego psychology and adaptation problem, New York 1958).

19 See J. Lacan, On the Names-of-the-Father, Cambridge 2005, 6-8. 
as they are relationships between comparables. There are two subjects - on the one hand, the ego, the individual ego, which following Freud and Sartre ${ }^{20}$, is actually an imaginary and mirrored form ${ }^{21}$, and on the other hand, the subject whom Freud called the "core of our being." The ego is a narcissistic mask, a psychologistical illusion, a fiction, a harlequin, offering an alienated and imaginary firmness.

Lacan situates the second subject, which he also calls the "true subject" (le sujet véritable), in the unconscious. In The Function and Field of Speech and Language in Psychoanalysis of 1953 and in Seminar 1: Freud's Technical Writings (1953/54) he describes the self-conscious subject by employing the French reflexive pronoun moi / mihi, in contrast with the true subject of the unconscious that he designates as je/ego.

The singularity of the subject must inscribe itself into a horizon of the general, because the "je" is absolutely irreducible to the individual. "C'estmoi" - This is $I$ is a type of reflexive sentence. However, for Lacan, reflection is a metaphorical expression that means nothing but "to mirror". The recognition in the mirror is an imaginary misunderstanding and leads to the division of the subject into moi (ideal ego, the "imaginary subject") and je, the subject of speech or of the unconscious. From this observation follows the paradox that sounds paradoxical: "The I is not the I" (le je n'est pas le moi).

The origin of psychic suffering is therefore not grounded in a weakening of the ego, but in its exaggerated reinforcement, which corresponds to the paranoid structure of the alienated ego and extreme madness. ${ }^{22}$ The unconscious, according to Lacan (as for Freud), is first of all to be distinguished from the conscious, but it is not irrational, because it is the revelation of a truth and not of any primal instincts.

This truth is the truth of desire. The word "desire" is a fundamental term in psychoanalysis and Lacan also claims a centrality of desire, at least until the publication of his Écrits. Lacan also translates desire with the word voeu - vow, vocation, endowment, "inasmuch as desire is the most intense of what the subject can reach at the stage of consciousness in its realization as a subject". 23

Desire is not a chaotic, fickle element but rather an element that orders existence as a vocation that guides, structures, and gives orientation to existence. When Lacan speaks of desire as a vocation, he wants to emphasize, on the one

20 J.-P. Sartre, The Transcendence of the Ego: Philosophical Essays 1931-1939, Reinbek near Hamburg 1982.

21 J. Lacan, The Seminar. Book I. Freud's Technical Writings (1953-1954), Berlin 1990, 212.

22 See Recalcati, Jacques Lacan. Desiderio, godimento e soggettivazione, Milano 2011, 34-41.

23 Lacan, On the Names-of-the-Father, 69. 
hand, that desire is not something that is directed toward mere objects in order to satisfy itself; on the other hand, he means that desire "is not the reservoir of wild drives that has to be conquered by the ego, but the site where a traumatic truth speaks."24

The Lacanian version of Freud's motto "where id was, shall I be" is that the I should not conquer the id in order for its enlightenment and the control of its instincts to progress. Rather, it means that the I should refer to the place of the id. The I should dare to approach the place of its truth, to make contact with the desire to listen to the call and the movement of desire.

Lacan thinks with Hegel (and with Hegel's interpretation of Alexandre Kojève) that desire is not one-sided, confined to negating or destroying the object. Rather, desire addresses another desire, namely the desire of the Other. It does not look for itself in the mirror, but in the Other. It is not a need that is directed at an object, but always lives in an intersubjective dialectic. Therefore, the subject always aims at a relationship that transcends the merely objective world, opening the existence to the possibility of desire (of the Other). Kojève expresses this with great power:

Human Desire, or better still, anthropogenetic Desire, produces a free and historical individual, conscious of his individuality, his freedom, his history, and finally, his historicity. Hence, anthropogenetic Desire is different from animal Desire (which produces a natural being, merely living and having only a sentiment of its life) in that it is directed, not toward a real, "positive," given object, but toward another Desire. ${ }^{25}$

Because of this structure, from the perspective of symbolic order, desire configures itself as a question of recognition. As Recalcati points out, "the human world cannot confine itself to the merely paranoid drama of narcissistic reflection: the subject is not exhausted in being alienated in its ideal image and therefore trapped in its double, but above all, it is part of the world of the symbolic, of that world which is guided by the law of the word". ${ }^{26}$

The mirrored nudity that mesmerizes the gaze of the I is not the symbolic "light garb" that protects the mystery of the subject, it "is rather a consequence of an attempt at absolute self-presentation (accompanied by the desire for a presentable God) in the mirror of one's own immeasurable desire". ${ }^{27}$ Lacan is

24 S. Žižek, How to read Lacan, New York 2007, 2.

25 A. Kojève, Introduction to the Reading of Hegel. Lectures on the Phenomenology of Spirit, Ithaca and London 1969, 6.

26 Recalcati, Jacques Lacan, 68.

27 K. Appel, Christianity and a New Humanism. Historical-Theoretical and Theological Reflections on the Bible, Hegel, and Musil. First Transition - From World Time to the Feast and Death, 9 . 
convinced that the narcissistic circularity of desire can only be interrupted by the law of the word.

The word, i.e. language, however, does not have a merely denotative function and must not be reduced to mere communication. The word transcends this schema, because it is an appeal, the call and invocation of the Other. It allows desire to be detached from the physiologically instinctive dimension of the needs in order to inscribe it in the human realm of symbolic gratification which is tied to the recognition between subjects.

While the "full" word is carried out by the Other, the "empty" word is full of the "I" and empty of the desire of the Other. If one is only an I, there is no room for desire, which is always the desire of the Other, so that, when the I is in the middle, there are only imaginary images of an empty desire. This means that the subject, as Lacan sees it, is always represented by a "signifier for another signifier." It is never the patron of its own being, nor can it be fixed in any identity, it can never consist of one single signifier.

The subject is always inscribed in the field of the Other. It is dependent on the latter's syntax, but at the same time it is always excluded from the Other's system insofar as there is no signifier that can completely determine subjective contingency. Here lies the power and vulnerability of subjectivity, which is characterized by a nomadic and unstable identity, subjected to infinite variations, open to possibilities of ever more recent subjectivations, and constitutively "gripped" by the field of the Other.

The crucial point in Lacan is the relationship between the symbolic law of the word and the law of desire. The subject of the unconscious is enlivened by desire; it is regulated by the symbolic order and by the function of the Father. With this figure, Lacan refers to the Big Other, i.e. to a third function whose declinewe perceive today in the cultureand processes of social transformation. ${ }^{28}$

The figure of the third breaks the symmetrical, imaginary and narcissistic reciprocity between I and other. ${ }^{29}$ The Big Other is eccentric to the mirrored other and not reducible to its reflection. It frees from the hypnotizing

28 J.-P. Lebrun / E. Volckrick (éd.), Avons-nous encore besoin d'un tiers?, Toulouse 2005.

29 Lacan's doctrine can be understood as a great meditation on the topic of narcissism. The theory of the mirror stage (J. Lacan, The Mirror Stage as Formative of the I Function as Revealed in Psychoanalytic Experience, in: ders., Écrits, 75-81) is one of Lacan's most famous concepts. According to Lacan, the I comes into the world between the sixth and the eighteenth month, when one holds it in front of a mirror. The child first recognizes itself as something different (as a reflected object in the mirror). It sees its unity, its whole corporeality only in its duplication in the mirror, before that it was only a fragmented (corps morcelé) body: the child responds to the knowledge and identification of itself in the mirror with a "jubilant gesture". However, at the same time, it is also depressed because it immediately understands that the image in the mirror is just an ideal image, a perfect idea of its identity to which the child will never adapt. This shows the dimension 
captivity in the mirror. The father as a third breaks down the "two-person relationships" internal to family or the mother-child unit and "intervenes as a third term, which is often experienced as alien or even unwanted". ${ }^{30}$ It is not only about the complex of weaning but also about the intrusion, the penetration of the Father into that enjoyment founded on the imaginary duality, the reflection "I and the Other".

Characteristics of these mirror relations are the "greedy separation" and the "jealous ambivalence" in relation to the other, whereas paternal sublimation makes it possible to triangulate this aggressive and erotic duality. Lacan calls this third term "name-of-the-father" or "name of the father", which is to be understood as a metaphor for a paternal function which does not necessarily have to be a biological or real one.

The instance of the Great Other indicates that there is a structural asymmetry in the human world that prevents a mere repetition of the same thing. What is needed is the positioning of the subject in relation to the other, or in relation to language, inscribing the subject itself in a tripartite relation and replacing the paralyzing fixations of the imaginary, i.e. the mirror relations:

In order for a relationship to take on its symbolic value, the mediation of a third personage is necessary who, in relation to the subject, th realizes the transcendent element thanks to which his relation to the object can be sustained at a certain distance. ${ }^{31}$

Human life is humanized through the intrusion of the paternal function, which implies the demand to be recognized by the Other. In the law of the word, namely in the place of the symbolic, the helplessness of the subject finds the possibility of becoming humanized. Every demand for the self-sufficiency of the I shows its constitutive inadequacy against this background. Already in Freud, the paternal function disrupts incestuous desire. As Freud points out in Totem and Taboo, an initial loss of limitless jouissance (the killing of the prime father, the father of the horde, who wants to possess all women) is the condition for a humanization of life and the possibility of desire (of the Other).

The humanizing power of fatherhood is also of fundamental importance in the Bible. Lacan's epigrammatic and enigmatic allusions to religion are scattered throughout his work. His concept of the "name of the father" and the epistemological triad of real, symbolic and imaginary, which is reminiscent of the Trinity, clearly refer to fundamental motifs of the Judeo-Christian tradition.

of helplessness that characterizes human life and the division that will shape the subject throughout its life.

$30 \quad$ B. Fink, The Lacanian Subject. Between Language and Jouissance, Vienna 2011, 85 .

31 J. Lacan, On the Names-of-the-Father, 28. 
This raises the question of the connection between the Jewish-Christian frame of reference and the father metaphor, or between the Lacanian version and the Jewish-Christian version of the father. It could even be said that the notion of "name-of-the-father" is itself biblical, insofar as the relationship with the father founds all other possible relationships and the dimension of subjectivity includes the possibility of recognizing oneself as a son.Jouissance is fundamentally characterized by the fact that it knows no moderation and no delay, because the drive to enjoy aims to have everything, be everything, and know everything. It is the denial of the human experience of limit and transcendence.

The symbol of the tree of knowledge points to the need for a postponement, as Appel writes, that is, an indeterminacy that opens up a space unreachable to human beings, "outside' the order of time (or to be more precise, beyond the inside/outside dichotomy)." 32 The tree of knowledge is therefore not to be interpreted simply as part of the negative register of prohibition but rather as a representation of the positive aspect of the gift of desire. The name of the paternal functions as a signifier by introducing the experience of the impossible into what is human. Biblically one could also call it the "seventh day."33

This represents the possibility of abandoning immediate, sensual and total jouissance, an enjoyment that is "enjoyed" without gaps or openings, in order that we may arrive at an understanding of language as the very condition for the possibility of desire. For Lacan, the "law of castration" is not simply the limitation of jouissance, the prohibition of the incestuous drive, the interruption of symbiotic and destructive fusion. It is, on the contrary, the very gift of language allied with desire. It means that when we enter the field of language, we lose direct contact with our libidinal body.

Thus, when we are subjected to the Big Other, we sacrifice our direct access to our own corporeality and can only have an access to it that is mediated by language. As the Lacanian psychoanalyst Charles Melman states, the act of inscribing the word implies that desire is organized on the basis of the absence of the object. Language sublates the "thing" and desire turns into a form of distance, lack, loss of the thing that is to be enjoyed, which places an aura of disappointment on every object.

Lacan presents the abstract subject "before language" with an S and considers it pathological. After the subject has accessed language (in the symbolic order), Lacan assigns the sign $\$$ to the subject ("split subject" or "locked

32 K. Appel, Christianity and a New Humanism. Historical-Theoretical and Theological Reflections on the Bible, Hegel, and Musil. First Transition - From World Time to the Feast and Death, B. The Gown of Grace and the Nakedness of Existence, 5-11. being a disposable totality that is to be filled by works and is under the control of man, and that time is exhausted in "world time". (3). 
subject"). What is barred or divided or separated here is the subject of jouissance, of the body, which stands in opposition to the symbolic order. The "Real of jouissance", namely, the One (and not the Other) as the center of the dimension of a libidinal, self-generated body which does not need the Other, is to be castrated so that the subject can enter the symbolic order.

The beginning of the symbolic implies the sublation of the thing, even if the symbolic order cannot extinguish the whole thing. Due to the impossibility of complete annihilation, the Big Other, as the ultimate instance of this order, harbors a remnant of inconsistency. In other words, it is structured around a defect, which is the lack of jouissance. There is always something left over that the symbolic order cannot grasp. This remainder is generated by language but represents something that language cannot symbolize.

Lacan calls this remainder, this surplus of the symbolic operation object petit $a$, or "small a". This indicates that the symbolic order cannot capture the whole of the real in its web. The subject's desire revolves around the object petit $a$, because it is precisely that which sets desire in motion, not as a material cause, but as a causative emptiness, a split in the subject, which causes its entry into language. Like the "seventh day", the object petit $a$ is "an addition, a space of opening, a leap and an elusive form of transcendence. To the extent that this day is not representable, it cannot be fully known by one particular discipline". ${ }^{34}$

One could say following Appel, that imaginary desire, that is, the desire of objects and the search for one's own satisfaction, seems to be reproducible and belongs to the first six days. The seventh day as the "object-ground" of desire "eludes objectification, and thus creates the space for the subjectification of man and for all living things, which, without this addition, would exist as mere zombies or machines, as the living dead." ${ }^{35}$ This addition is at the same time a lack of jouissance and an excess in desire.

The law of castration as an effect of language introduces this unimaginable dimension into life. For Lacan, is not merely the threat of emasculation but a symbolic interdict that simultaneously represents and effects the introduction of the subject to the experience of the limit and the impossible. The law of the Father introduces the impossible and thus corresponds to the traumatic but also healing power of the law.

It is traumatic insofar as it deprives us of the object of jouissance, but at the same time it is wholesome, because the existence of the law has the purpose of making desire possible. In this sense, the experience of the impossible first

34 Ibid.

35 Ibid. 
enables the possibility of desire. Lacan's designating the father metaphor the "name of the father" clearly addresses the question of prohibition and the law through the French homonymy of nom / non. The father is the substitute, the mediator of the law, and in this function enables the child to be separated from the mother and thus the constitution of the subject.

In The Subversion of the Subject and the Dialectic of Desire in the Freudian Unconscious (1960), Lacan writes that the Father can reconcile the law and desire with one other, although this only happens in an unsatisfactory way because the will to enjoy impedes this pact of law and desire. Lacan even speaks of a "kind of co-conformity between them"36 and thinks that no one understood the dialectic between desire and law better than Saint Paul. ${ }^{37}$

As Paul has already noted, law and desire arise essentially simultaneously (Rom. 7:7), although this origin is to be understood beyond any literal interpretation of the law. This means that it is necessary to avoid the trap of a law that nourishes its own transgression in order to assert itself exactly as a law. When law separates from desire (and thus perverts it), it becomes either the bureaucratic law of society or the family and small order without desire, or the deadly and inhuman law of the concentration camp.

Therefore, according to Lacan, it is necessary to transcend the idea of a superego law as the humiliation and sacrifice of desire. It is an inhuman and succinct law that generates resentment and aggressiveness. In the scene of the meeting of Jesus and the adulteress (Jh 7:53-8:11), this literal automatism of the law comes into play in an exemplary manner. While the scribes want to stone the woman in the name of the law of Moses, Jesus puts the situation on another level, namely forgiveness and love. "And when they heard this, they went out one by one, beginning with the elders" (John 8:9). The superego is indeed not an heir of the law but its usurper unable to speak a saving word. It knows only one judgmental and deadly word that transforms us into living dead. As Paul writes: "For the letter kills, but the spirit gives life" (2 Cor 3:6). In a similar way, Lacan claims:

36 J. Lacan, On the Names-of-the-Father, 84.

37 "I believe that for a little while now some of you at least have begun to suspect that it is no longer I who have been speaking. In fact, with one small change, namely, 'Thing' for 'sin,' this is the speech of Saint Paul on the subject of the relations between the law and sin in the Epistle to the Romans, Chapter 7, paragraph 7. [...] The relationship between the Thing and the Law could not be better defined than in these terms." (Lacan, The Seminar, Book VII, The Ethics of Psychoanalysis, W.W. Norton \& Company, New York / London 1997, 83). 
We will have to explore that which, over the centuries, human beings have succeeded in elaborating that transgresses the Law, puts them in a relationship to desire that transgresses interdiction, and introduces an erotics that is above morality. ${ }^{38}$

In the same vein, Slavoj Žižek asks whether in a Pauline perspective it would not be possible to think "love within the confines of the Law, love as the struggle to suppress the excess of sin generated by the Law". ${ }^{39}$ According to Paul, love is not merely a transgression or annulment of the law, but rather its abrogation, in which alone the law can find its fulfillment. ${ }^{40}$ In fact, a desire encounters an opposite risk when it breaks the law. When desire emancipates itself from the law, when it breaks away from castration, it becomes jouissance mortelle, namely, the will to enjoy until death.

Here, in fact, the dimension of love opens up, which is the only real possibility for Lacan, as he writes in Seminar $X X,{ }^{41}$ of reconciling life as jouissance and life as desire.

\section{The Father of the Covenant and the Master of Power}

This alliance of desire and law, desire and word is at present threatened, inasmuch as the desire becomes jouissance, i.e. the desire without castration, without limit, without word. What is needed is the biblical Father of the covenant, who makes possible the humanization of life. Opposite him stands the Father of Power, the Father of the Federation, the forefather of the Freudian Totem and Taboo. The Father as a figure of sublimation can be understood as the answer of Lacan to the Father as leader, as Duce - whom the masses worship.

Lacan sees the return of the totemic Father and the longing for his absolute protection without fail as closely connected with the social downfall and the

38 J. Lacan, The Seminar. Book VII, 104.

39 S. Žižek, The Fragile Absolute: Why is the Christian Legacy Worth Fighting for?, London / New York 2000, 100.

40 With regard to the dialectics of law and love in Paul and in the young Hegel, I would like to refer to I. Guanzini, Il giovane Hegel e Paolo. Lamore fra politica e messianismo, Milano 2013 and, from the same author, Katargein and Aufheben: Paulinian Origins of Hegelian Dialectic?, in: Annali di Scienze Religiose 7/2014.

41 “A subject, as such, doesn't have much to do with jouissance. But, on the other hand, his sign is capable of arousing desire. Therein lies the mainspring of love. The course I will try to continue to steer in our next classes will show you where love and sexual jouissance meet up. "See J. Lacan, The Seminar. Book XX. Encore (1972-1973), New York / London 1998, 5 . 
epochal evaporation of the Father. The great totalitarian ideologies are, according to Lacan, an attempt to nostalgically reclaim a more archaic matrix. They represent a perverted form of the Mother as a metaphysical illusion of universal harmony. The father-leader appears at the same time as a dramatic compensation for the impotence of the Father. ${ }^{42}$ This description of the Father can be found in The Seminar. Book III (1955-1956). The Psychoses, which deals with the treatment of psychoses and contains important considerations of Lacan's paternal function. ${ }^{43}$

Lacan's psychoanalysis, as we have seen, is not free from theological undertones. This is also shown by the fact that psychosis develops its own form of theology, which can be grasped in a similar way to Christian theology. In contrast to the biblical figure of the Father as word and covenant, Lacan shows that in the psychotic subject, a theological delirium unfolds, in which the other is the place of subjugation and abuse that oscillates between an excessive presence and an unmotivated withdrawal. For Lacan, this degradation of the symbolic covenant down to arbitrary power means the negation of the possibility of a humanization of life through the generation of subjective desire.

The "Schreber Case", which is a classic case in psychoanalysis and is at the center of this Lacanian seminar, represents nothing but the embodiment of the lack of the symbolic, i.e. the rejection of the paternal function. In his book Memoirs of My Nervous Illness, a Complex and Comprehensive Report on His Paranoia and Delusions, analyzed by Carl G. Jung, Sigmund Freud, Elias Canetti, William G. Netherland, and Jacques Lacan Dr. Daniel Paul Schreber (1842-1911), President of the Senate at the Dresden Higher Regional Court writes:

In any case, the whole idea of morality can arise only within the Order of the World, that is to say within the natural bond which holds God and mankind together; wherever the Order of the World is broken, power alone counts, and the right of the stronger is decisive. In my case, moral obliquity lay in God placing Himself outside the Order of the World by which He Himself must be guided. ${ }^{44}$

While the figure of the Father in the Judeo-Christian tradition is the place of the logos, the law, and the order of the world, in psychosis the Father is the place of fundamental disorder and dysfunction - i.e., the place of chaos and lack of law. Psychosis comes along with the absence of the paternal signifier,

42 See Recalcati, Jacques Lacan 145-147; M. Recalcati (ed.), Forme contemporanee del totalitarismo, Torino 2007 .

43 J. Lacan, The Seminar. Book III. The Psychoses, W.W. Norton \& Company, New York / London 1997.

44 D.P. Schreber, Memoirs of My Nervous Illness, New York 200o, 66. 
which Lacan calls "forclusion" and in which the symbolic paternal function is overridden. God, for Schreber, remains indifferent to his creation, which becomes completely passive. This God does not understand human needs and only wants to enjoy his creatures. He is a radical and sadistic version of the jouissance of the Other that does not guarantee the world order and nor protects his creation. His existence is the fundamental perturbation of the universal order and his characteristics consists in the fact that he always speaks:

So, here is this God, then. We already know it's he who is always talking, who is forever talking without saying anything. This is so much so that Schreber dedicates many pages to considering what it might mean, that there is this God who talks without saying anything and who nevertheless never stops talking. ${ }^{45}$

The function of language is completely destroyed in psychosis insofar as that which speaks is not the subject but rather language itself. The language of the Other speaks the subject, so that the subjective word is abolished through its being spoken by the Other. Bruce Fink writes:

Psychosis, according to Lacan, results from a child's failure to assimilate a "primordial" signifier which would otherwise structure the child's symbolic universe, that failure leaving the child unanchored in language, without a compass reading on the basis of which to adopt an orientation. A psychotic child may very well assimilate language, but cannot come to be in language in the same way as a neurotic child. Lacking that fundamental anchoring point, the remainder of the signifiers assimilated are condemned to drift. ${ }^{46}$

All imaginary disturbances and cataclysms of the psychotic subject are due to a dysfunction of the Other, that is language, in a hole in the symbolic order, in a rejection of the paternal signifier, which Lacan also calls master signifier. ${ }^{47}$ The psychotic subject has not assimilated the master signifier or the name of the father, so that the symbolic inactivity of the paternal function leads life into absurdity - such as in melancholy - or allows life to be flooded with meaning and words. In this case, the subject experiences (linguistic) paranoia.

\footnotetext{
45 Lacan, The Seminar. Book III, 126.

46 B. Fink, The Lacanian Subject. Between Language and Jouissance, Princeton 1995, 55.

47 The symbolic order consists of a "chain of signifiers" (chaîne de signifiants), which is assigned, structured and guaranteed by the existence of a "master signifier" (name-ofthe-father). The master signifier enables the subject to take a firm place in the symbolic. See E. Laquièze-Waniek, "Lord Significant": discourse, symbolic order and change of power in Jacques Lacan, in: I. Gurschler / S. Ivády / A. Wald (ed.), Lacan 4 D. The Four Discourses in Lacan's Seminar XVII, Vienna / Berlin 2013, 165-195.
} 
The comprehensive extension of meaning in which the transitive nature of things is over-determined, however, removes meaning. ${ }^{48}$ This wavering between a meaningless life and a flood, an unlimited expansion of meaning corresponds to the wavering of the psychotic subject. Either life does not make sense, or all nonsense dissolves. ${ }^{49}$

Life is a question of meaning, and the Father should be the one who brings life and meaning together, though this does not mean that the Father should have the last word on the meaning or nonsense of life, but a word of recognition and a word of lack. The paternal function has the task of showing the limit of symbolization by referring to the dimension of the real, that is, to something that defies the process of symbolization but is indispensably dependent on representation.

The paternal answer cannot simply protect against the burning, treacherous, and contingent encounter with nonsense. This would be the characteristic of the neurosis, which is a "passion for justification" that cannot endure any shortage. For Lacan, therefore, it is necessary to distinguish the speech of the Father from the speech of the master, because the Father has to be the one who can give the word and therefore the one who is able to lose the word and to remain silent.

The dialectic of silence and speech, of desire and law, of paternal function and individuation, of jouissance and castration is overridden in

48 This tendency towards over-interpretation, which leads the world perception to the brink of breaking, finds an explicit representation in The Goalie's Anxiety at the Penalty Kick by Peter Handke. Jakob Deibl mentioned a passage of this book in order to illustrate the abundance of meanings and metaphors: "Bloch, who had already observed a lightning rod at school, immediately took this repetition to be intentional; it could not be a coincidence that he hit a lightning rod twice in a row. Here the referential nature of things in the world, which can never be viewed as isolated from each other, is increased up to the limit of the collapse of a meaningfully interpretable world. The relational structure in which all things stand is overstretched, almost endlessly extended, everything is a metaphor for something else and can stand for everything else. Things and events are constantly questionable and relevant regarding their meaning, because there always has to be something else to be found behind them. "(J. Deibl, Narration and Transformation by Peter Handke, Hölderlin Metamorphoses in the "Repetition”, in: J.-H. Tück / A. Bieringer [Hg.], Transforming by counting only. Peter Handke in the area of conflict between theology and literary studies, Freiburg i. Br. 2014, 159f.)

49 "This discourse which is presented to the subject Schreber at the period of the illness he's describing has a dominant characteristic of Unsinn. But this Unsinn is not entirely simple. The subject who is writing and confiding in us depicts himself as undergoing this discourse, but the subject who speaks -and the two are not unrelated, otherwise we wouldn't be characterizing him as mad - says some things very clearly, such as what I've already quoted to you, Aller Unsinn hebt sich auf! All nonsense is annulled, rises, is transposed!" (Lacan, The Seminar, Book III, 122). 
psychosis. The absence of the paternal function leads to the destruction of any articulation of the relation between message and code, and therefore into a catastrophe of signification. The place of the Other transforms from being the condition of language into a place of persecution. The singular word (parole) no longer finds its structure and its condition of possibility in language (langue), but language speaks the subject and makes it idle. ${ }^{50}$

Therefore, it seems necessary to consider the subject as surplus and resistance rather than passive dependence on the signifier. Without the inscription into the symbolic, the singular dissolves into an inconsistent individualism, while the universal, unrelated to the singular, evaporates into general emptiness. We are not mere machines or fictions of the symbolic order, which, because only language (langue) speaks, cannot pronounce a word (parole).

Like the replicants in Blade Runner, who have false, programmed, and fictional memories, we can recount, subjectivize our memories so that they can become one story. What is at stake here is the responsibility of subjects in terms of the possible variations and unfoldings of the symbolic order. The process of subjectivation is realized through the imprints and contingent inscriptions in the field of the Other which singularize the universality of the structure. Subjective life can be understood as a complex arc of this daily rewriting of a collective text, within a space of resistance and exposure, of acceptance and closure, of enthusiasm and disappointment.

The crucial question, which is both ontological as well as ethical and anthropological, concerns the possibility of such a form of subjectivation. It is always an actual "resurrection" of "being a subject" within the symbolic order, and this as a singular, vulnerable, and contingent vocation to move with intensity and parrhesia within the discourse of the Other, i.e. without indulging in one's own desire..$^{51}$ The subject is always subjected to the Other, but it is also the constant possibility to subjectivize this submission. How can one subjectivize one's subjection to desire? is thus the guiding question.

50 See Recalcati, Jacques Lacan, $159^{-162 .}$

$5^{1}$ The only fault that recognizes Lacan is "giving up on one's desire" (Seminar VII). "Ne pas céder sur son désir" is the basic principle of the ethics of psychoanalysis for Lacan. It is about an infinite responsibility that leads the subject to understand that there are no signifiers, no one else who can take that responsibility in my place. When psychoanalytic ethics asks about the problem of human satisfaction, it is first about the call to have one's own desire received in a singular way. Did we absorb the urge of our own desire or did we betray it? The betrayal of this urge is what Freud called "repression." Repression can also be interpreted as a betrayal, an avoidance of the ethical task of absorbing desire in a singular way. Repression means not wanting to know about it, it is ignorance of desire. Lacan claims that the ethics of psychoanalysis leads to the acceptance of one's own desire, which as a sign of faithfulness to this desire has to constantly be repeated. 


\section{The Ruse of Capitalist Reason}

When Lacan emphasizes that the Big Other no longer exists, he also intends to say that the symbolic order, namely the law of language, is no longer able to orient life. Therefore, human enjoyment aims to go beyond boundaries and refuse the experience of the impossible. We live in the age of the "evaporation of the Father". This announces a society without third and especially without the big third, which prohibits the actual possibility of desire.

Massimo Recalcati and Charles Melman diagnose a tremendous transformation that has incalculable anthropological consequences. ${ }^{52}$ They notice the direct link between a liberal, unleashed economy and a subject that is free from past and future generations and therefore without future nor past.

Charles Melman speaks of people without gravity, quasi-mutants who have processed, internalized, assimilated the market model and filter their relationship with reality through the paradigm of positivist scientism. Within a human landscape in which the objects of consumption multiply again and again and new possibilities of existence are constantly produced, desire is repressed or even annihilated.

For Lacan, the discourse of the capitalist is a discourse of the dissolution of all relationships. The subject is led to establish itself in the immediate satisfaction of its objective needs, in a continuously exalted enjoyment of all attachments. ${ }^{53}$ Therefore, it is a discourse at the limits of discourse, starting from the moment in which it transcends the law of the word, to affirm the domination of the object and the enjoyment of the One without difference, instead of asserting the desire of the Other.

In the present epoch, the occidental ego tends to settle in the field of the One, where everything seems to demand to be grasped and consumed, and where ultimately consumption itself is consumed. It could be said that the subject even consumes nothingness by successively abstaining from anything substantial. It is emptied of any content containing history, hope or injury and encounters its actual nudity. Appel states, "that the human being finds himself confronted with an almost inscrutable, all-absorbing emptiness (the "Evil")".54

52 See M. Recalcati, Luomo senza inconscio. Figure della nuova clinica psicoanalitica, Milano 2010; Ch. Melman, La nouvelle économie psychique. La façon de penser et de jouir aujourd'hui, Toulouse 2009; J.-P. Lebrun, Un monde sans limite. Essai pour une clinique psychanalytique du social, Toulouse 2007.

53 Cf. P. Bruckner, L'Euphorie perpétuelle. Essais sur le devoir du bonheur, Paris 2001.

54 K. Appel, Christianity and a New Humanism. Historical-Theoretical and Theological Reflections on the Bible, Hegel, and Musil. First Transition - From World Time to the Feast and Death, 7 . 
Gilles Lipovetski has referred to our time as the "era of emptiness" 55 to designate the post-revolutionary and post-traditional, permissive and individualistic stance of the postmodern era, in which absolute presence dominates. This means that any relationship with the "eschatology of desire" and therefore with the dialectic of attraction and repulsion of the object $a$ must yield to the immediate consumption of the ever-available goods, within the nihilistic circularity of a timeless flux.

Within this scenario, the current atmosphere feeds on what Badiou calls a "generalized desire for atonality". ${ }^{6}$ In this, social atomism and the emptiness of references produce the general illusion of a self-construction of the ego without limits, orientations and prohibitions. The subject becomes the plaything of the inescapable abyss of jouissance, i.e. an expansion of what one considers one's own in every possible direction. Fredric Jameson speaks of a decay of affectivity: it is not that the postmodern era is without feeling, but it fluctuates freely, impersonally, and tends to be dominated by a specific "kind of euphoria" 57 which lacks the intensity of memory and intimate temporality in order to focus instead on the synchrony of a present "without gravity".

The enthusiasm of this unleashing, initially perceived as a liberating detachment from the inanimate bonds of our conditioning and the imperatives of a society defined by discipline, gives free rein to the process of psychologizing meaning, in which relationships without commitment feign to be able to stay alive outside the fertile soil of a collective humus. The hypermodern state of our society is characterized by an emptying of the symbolic order, i.e. by the emptying of the figure of the Father and of the law of the word.

Although Lacan's entire psychoanalytic perspective is, as it were, circling around the question of the "name of the father," Lacanian psychoanalysis by no means seeks to rehabilitate the traditional paternal function but to discuss the question of the consequences of its dissolution. Lacan seeks to designate not only an epoch of liberation from the firm and despotic ideals of tradition but also a time of chaotic drift and destabilization, in which, paradoxically, the subjects, following their liberation, flee into authoritarian and despotic identities and dissolve within the individual cult of the object.

The border(s) and the frictional resistance that promote the desire and vitality of the subject are pulverized. Thus, an existence that seemed capable of finally being considered to be liberated and emancipated becomes

55 G. Lipovetsky, L’ère du vide. Essais sur l'individualisme contemporain, Paris 1989.

56 A. Badiou, Logiques des mondes, Paris 2006, 443.

57 F. Jameson, Postmodernism, or The Cultural Logic of Late Capitalism, in: New Left Review 146 (1984), 64. 
extremely susceptible to whispers. A double bind between the narcissistic search for absolute and individual freedom and indirect forms of control and manipulation ultimately proves unmanageable to the subject, sliding between rushed jouissance and the absence of the law.

This leads to a weakening and an erosion of identity. The Italian philosopher Fulvio Carmagnola states that we are currently living in a context "where oversight turns into blindness, into potential cynicism".58 We are immersed in constant insecurity, between amazement and terror, trust and cynicism, passivity and omnipotence. Today's subject, like Eric Packer, the protagonist of Don DeLillo's novel Cosmopolis, feels "overly cautious, lethargic and incorporeal".59 This 28-year-old billionaire in his limousine, which spasmodically compresses all space and time, represents the incarnation of finance capitalism, giving shape to a new contemporary eloquence of alphabets and numerical systems moving in the binary grammar of the new digital world.

I put out my hand and what do I feel? I know there's a thousand things you analyze every ten minutes. Patterns, ratios, indexes, whole maps of information. I love information. This is our sweetness and light. It's a fuckall wonder. And we have meaning in the world. People eat and sleep in the shadow of what we do. But at the same time, what?60

The ruse of capitalist reason and its discourse is the ability to systematically exploit the constant excitement and widespread disorientation and install it as a kind of system. Today spontaneity, individual expression and self-realization are imperatives in a society of universal consumption, in which enjoyment, in a cunning and all-pervading way replaces traditional duties and is directly subordinated to the capitalist circulation of goods.

Capitalism is thus in some ways more compromising and suppressive than the antique commandment. Pasolini put it this way: the subjects have become consumers. ${ }^{61}$ In a famous lecture held in Milan in 1972, Lacan speaks of the

$5^{8} \quad$ F. Carmagnola, Il consumo delle immagini. Estetica e beni simbolici nella fiction economy, Milano 2006, 95 .

59 D. DeLillo, Cosmopolis, New York 2003, 6.

6o Ibid., 7 .

61 In the introduction to The Practice of Everyday Life, Michel de Certeau describes this condition with a certain harshness: "The purpose of this work is to make explicit the systems of operational combination (les combinatoires d'operations) which also compose a "culture," and to bring to light the models of action characteristic of users whose status as the dominated element in society (a status that does not mean that they are either passive or docile) is concealed by the euphemistic term "consumers." Everyday life invents itself by poaching in countless ways on the property of others." (M. De Certeau, The Practice of Everyday Life, Berkeley 1984, xi et seq.) 
"discourse of the capitalist," which is an extension of the "discourse of the master," which emerged from the historical affirmation of capitalism. ${ }^{62}$ Market society globalizes the necessity of "unrepentant consumers", namely, consumers who do not feel shame in their enjoyment and who do not conceive limits for themselves. The discourse of the capitalist operates in a circularity without interruptions, as a perpetuum mobile of continuous production and distribution.

In order to gain a key to the understanding of the so-called post-modern epoch, it seems helpful to turn to some Spinozistic concepts such as possible affects and the intensity of existence. Today, we are confronted with an expansion of "sad emotions" 63 that suppress social aliveness and lead to a decline of the vis existendi and the potentia agendi of the subjects and of the entire Western society. These are affects that bring about unexpressed moods within the social body, nourish sinister and sad feelings.

Spinoza's philosophy represents the first attempt by occidental modernism to de-traumatize or aestheticize the contingency of being.

This is accomplished by assigning a fundamental ontological value to the sensitive inner structure of enjoyment (happiness) as the sole meaning of desire. One could speak of an ex-timity, ${ }^{64}$ i.e. a subjective-objective space in which the shape of the world finds its rationality and convenience in the unfoldings of the enjoyable joy of the individual. Joy, then, becomes the image of the rational fulfillment of being, not just the sentimental reflex of pleasing. In this sense, the model of Spinoza perfectly illustrates the postmodern attempt of a comprehensive aestheticization of life's contingency as such, that is the ideal of a perfect overlap of the principle of reality and the principle of the enjoyment of life.

In Part V of his Ethics Spinoza elaborates a theory of affects that plays a central role in his ontology and understanding of the world and which should be understood as an "affirmation of life." According to Spinoza, man is first and inevitably entrusted to his own emotions. For Spinoza, the affections are the

62 J. Lacan, Radiophonie, television, Torino 1982. For Lacan, the discourse of the master represents the function of prohibition and interdiction as a universal rule, in which the power of the signifier imposes rigid identifications upon the subject and thus the rule of the law.

63 See M. Benasayag / G. Schmit, Die verweigerte Zukunft: Nicht die Kinder sind krank, sondern die Gesellschaft, die sie in Therapie schickt, München 2007 (or Les passions tristes. Souffrance psychique et crise sociale).

64 Extimity is a neologism by Lacan that associates the prefix "ex" - meaning "out- side", extraterritoriality - with the adjective intime that refers to intimacy, the interior. Thus, the extraterritorial nature of that which, to subjectivity, is the most intimate is signified. 
imprints that humans leave to each other by activating the creative power of sensibility. In the experience of the affectus, the subject is led outward, outside of itself.

The moment one touches and is touched, one's own "relational energy", as Luce Irigaray would say, is directed toward the other. In doing so, the world is constructed. ${ }^{65}$ Any passion that implies a reduction in the potential for action is called tristitia (grief), while laetitia (joy) denotes the passion in which it grows. Joy and sorrow also signify the proportion of activity and passivity of a human life. ${ }^{66}$ For Spinoza, grief is "man's transition from greater to lesser perfection". ${ }^{67}$ As soon as one feels sadness, the body falls into passivity and stagnation.

This sadness is heightened by the fact that the subject is constantly experiencing the social imperative of "feeling good" about himself, so that he also perceives his sad situation as his own fault. For Spinoza, a mode is an "inadequate cause" if it does not extend into the living flow of living affects but represents an unfruitful self-affection. Such self-affection interrupts the possibility of successful encounters in order to actuate the singular potency of existing in a forced isolation in which the relational abilities dry up and the passivity of life prevails.

Therefore, Spinoza's politics consists in the texture of living relations that create openings in the state-body that become critical instances in face of a repressive regime. For power reduces the circulation of affects. It loves sadness because the sad mode does not move but obeys without appreciating possibility. Thus, sadness never leads to "intelligence" because it reduces agency by leading existence into a vicious circle of consistent closures.

For this reason, powers and governments rely on the sadness of the subjugated, who are increasingly exposed to the power of the Other and thus weak and passive regarding their agency. Sadness will never create "common concepts" or relational intelligence between bodies but will be exposed to the randomness of encounters and subject to discordance and seclusion. Following

65 Luce Irigaray claims that "human energy is not just about growing, as it occurs or at least seems to occur in the plant world. There is a relational energy to be experienced and educated because it is human. This type of education is still absent in our culture. The majority of us live most of our own lives split between a non-educated energy in terms of their own sexual orientation and a formally codified and imposed modality of appearance and action that is inappropriate to their own nature" (L. Irigaray, Elogio del toccare, Genova 2013, 11).

66 G. Deleuze, Cosa può un corpo, Verona 2007, 58. See A. Böhler, Deleuze in Spinoza Spinoza in Deleuze, in: V.L. Waibel (ed.), Spinoza - Affektenlehre und amor Dei intellectualis, Hamburg 2012, 167-186.

67 B. de Spinoza, Complete Works, Ethics in Geometric Order, E 3, Definition of affects 1-3. 
Spinoza, one could say that today's widespread sadness is an expression of the spread of a general melancholy, which appears like a subtle "radiation" of resignation and euphoria.

Some critics speak of a new psychic econom ${ }^{68}$ and of new subjects. These are not just simple changes in Western societies, but a hitherto unknown "anthropological mutation" 69 that fosters profound individual and collective changes of our emotional household. It affects the mindset, the actions, the mode of our desire and the general understanding of the subject.

According to Lacan, whereas the "discourse of the master" legitimizes itself according to a hierarchical conception of power and autonomy, the "discourse of the capitalist" is grounded in an unlimited circulation of goods and everyone's right to their own enjoyment. The "inner-worldly asceticism", which according to a hypothesis by Max Weber made possible the arrival of capitalism, turns into an invitation to consume, to enjoy consumption. The uninterrupted cycle of objects creates the illusion that in infinite consumption, the "void of being" of our existence may find fulfillment.

The circulation of capital is kept alive by a proliferation of small jouissances and inauthentic discourses manifesting themselves in the obsessive supply of gadgets, fictional objects of desire - empty words, as Lacan would say. Such objects of enjoyment, of discourses, of culture, of industry, of sublimation extend to everything that seems potentially capable of filling a fundamental void, that of the true lost object. This generalization of excess in the free market reverses the nature of the "lost object": The surrogates that make the system shine produce a portrait of the "thing" that tends to fill every void, culminating in a psychotic ending. ${ }^{70}$

In reality, the "thing" that stands for the enjoyable fusion with the maternal origin is precisely that which resists any signification, that which has no object and around which lies the "gravity" of a deep silence, a radical alterity, a void that abolishes all subjective attempts to represent one's own desires. The immediate enjoyment of the thing is a kind of "rejection" of the great visionary desire -, in the context of this rejection, J.A. Miller speaks of a renunciation

68 C. Melman / J.-P. Lebrun, La nouvelle économie psychique: La façon de penser et de jouir aujourd'hui, Toulouse 2009; M. Fiumanò, L'inconscio è il sociale. Desiderio e godimento nella contemporaneità, Milano 2010; Recalcati, L'uomo senza inconscio.

69 Pier Paolo Pasolini had already written of an "anthropological mutation" with regards to the deep transformations that came with the arrival of consumer society. This mutation consists in the impoverishment of human space and the tragic destruction of singular qualities, be they superficial, deep, or spiritual. See P.P. Pasolini, Lutheran Letters, Manchester 1983 .

See S. Žižek, The Ticklish Subject, 369-377. 
of the "heroic paradigm" - in the name of a cynical materialism relative to the drives that expresses the nostalgic return to the oedipal father without recognition nor gift. ${ }^{71}$

The effect of subjective enjoyment is a new bio-power ${ }^{72}$ in post-industrial Western societies. This manifests itself as a practice that is not characterized by desire and passion but by indifference. The ethical imperative of the permissive zeitgeist, which stands in radical opposition to the repressive prohibitions of the premodern society of order and discipline, is: “Enjoy!". It is characterized by the fact that it has made excess the normality of existence. Desire takes on a despotic form that no longer seems sustainable today.

It drowns in jouissance, which, paradoxically, the prohibition to enjoy turns back into a prohibition of not enjoying. This prohibition is no longer organized around a guilt complex but rather a not-measuring-up. Being "in shape" and imperatives like "Be who you are!", “Be happy!", or "Enjoy yourself!" are proving to be the contemporary global imperative of pluralistic Western societies that lacks a moral and cultural horizon shared by all. But this production apparatus simultaneously creates and empties desire by there being "nothing" beyond the objects. The goods are not a substitute of the object a, but phantasms without gravity, which cannot convey well-being.

A perfect expression of such an all-pervasive aestheticization is the character of the Jeune Fille (The Young-Girl) ${ }^{73}$, designed by a collective and anonymous (de-subjectivized) writing team, a radical dispositive transforming and radicalizing commodity ideology into an imaginary anthropology in which the question of existence is conceptualized as a problem of management and the figure of the total consumer is drawn. These are some of the characteristics and expressions of the "Young-Girl": "I want people to be beautiful." ... "The Young-Girl knows so very well the value of things." ... "The

71 The psychoanalyst and publisher of Lacan's seminars Jacques-Alain Miller writes: “Lacan calls them lichettes, a small piece of jouissance. Modern society is full of such substitutes to jouissance, little trifles. The small pieces of jouissance are characteristic of a certain lifestyle and a mode-de-jouir (J.-A. Miller, Paradigmas of Jouissance, in: Lacanian Ink 16, New York 2000, 33).

72 V. Codeluppi, Il potere della marca. Disney, McDonald's, Nike e le altre, Torino 2001.

73 Tiqqun, Preliminary Materials for a Theory of the Young-Girl, Cambridge MA 2012. Tiqqun is the name of a collective that publishes the magazine "Tiqqun" in Paris. The chapters of the book are, among other things: "The young-girl as self-technology"; "The young-girl as a commodity"; "The young-girl as living money"; "The young-girl as a compact political dispositif"; "The young-girl as a war machine"; "The young-girl against herself: the boy-girl as impossibility". [TN: In the present examples, the use of "jeune" represents a pun on its two meanings, namely "young" and "young adult". "Jeune Fille" or "Junge-Mädchen" could thus also be translated as "boy-girl".] 
Young-Girl never creates anything; all in all, she only recreates herself. "..." The Young-Girl invariably calls "happiness" everything to which THEY chain her".

The Young-Girl is never simply sad, she is also sad that she's sad. "..." The young-girl wants to be desired without love or loved without desire."74 As these quotes show, the young-girl seems to be programmed for seduction, youth and desire. His / her experience ultimately results from being docile regarding any oppression and suggestion, so that his / her language and feelings are systematically directed by an economic, cosmetic, and mimetic machine, aiming at incessant entertainment by the merchandise spectacle. Self-care is directly linked to the totalitarian control of each stage of life, insofar as it is "human capital" that must be offered and handled in a continuous presentation and display of oneself.

\section{The Aestheticization of the Lifeworld}

In the time of the "vaporization of the Father", what remains is the enjoyment of the appearance that the world of goods and "images" offers us. There remain "technocratic strategies", as Michel de Certeau calls them, ${ }^{75}$ namely, the way to navigate between habit and invention. The "discourse of the capitalist" exaggerates enjoyment and fragments the affective forms of relationships. It feeds on the ideology of the homo felix, who aligns his life to a time without a feast following the illusory ideal of the narcissistic satisfaction of one's own potential.

There is no life without "an addition not amenable to projection or prediction, in other words a contingent-random one"76. In the terms of Lacan, this supplement would be the object $a$, insofar as it is an object that has always been lost, namely, that passion that orientates and attracts the desire of the object without it being possible to represent it. According to Spinoza, it is the possibility

74 Tiqqun, Preliminary Materials for a Theory of the Young-Girl, 23-28.

75 De Certeau, The Practice, 85-92.

$76 \quad$ K. Appel writes: "Time (or world time) is thus fundamentally more than the accumulation of its moments. It becomes human only at the point where chronos is lifted in favor of the no longer representable feast. Preparations are certainly made for this feast in the time preceding it, often down to the tiniest detail, but it gets its force from an addition not amenable to projection or prediction, in other words a contingent-chance one. Perhaps at this point we might start to ask whether the way in which the "superfluous" (superbundant) chance qua chance expresses itself celebratorily is not in fact a key aspect of the feast." (K. Appel, Christianity and a New Humanism. Historical-Theoretical and Theological Reflections on the Bible, Hegel, and Musil. First Transition - From World Time to the Feast and Death, A. The Seventh Day, 4). 
of that which exists to inscribe its natural existence in the substance according to the variations and developments of its own vis existendi and potentia agendi.

In the infinite production of contingent existences that compose an affective texture of the world, separation is overcome only in working on something collective, in the pleasurable circulation of encounters and good relationships within a social body that constitutes the substance of life. In contrast, the flow of goods and the endless entertainment offered by the media and the internet, which (re-)produce a texture of digital humanity every day, weaken that collective texture and dramatically reduce the field of variations and "gravity" of living social relationships.

Alain Badiou is convinced that ruthless self-censorship, namely, a civil program of self-restraint and discretion, is the conditio sine qua non of any politics of emancipation. An excessively tolerant approach does not take into account the fact that today power no longer resides in censorship but in an infinite permissiveness that, as Badiou says in Fifteen Theses on Contemporary Art's fourteenth thesis ${ }^{77}$. In the absence of borders and sources of friction, in fact, everything is in free fall. Everything happens at the same speed without interruption. What is missing is grounding and the connection necessary for a web of relationships and a common world of reciprocal and vital alternations and attractions.

We are currently experiencing an uncertain state of vision, caught between technological fetishism and constant skepticism concerning the visible, which calls for the question of the true nature of human experience. ${ }^{78}$ This question is at the center of the fundamental dynamics of post-industrial societies, in which, as Vitta notes, "the process of history is bluntly diverted: the world of 'forms' has changed the 'form' of the world."79

The aesthetic construction of the shapes and images becomes the dominant tendency of our new industrial and consumerist affluent society. The

77 "14. Since it is sure of its ability to control the entire domain of the visible and the audible via the laws governing commercial circulation and democratic communication, Empire no longer censures anything. All art, and all thought, is ruined when we accept this permission to consume, to communicate and to enjoy. We should become the pitiless censors of ourselves" (A. Badiou, Fifteen Theses on Contemporary Art, in: Lacanian Ink 23, New York 2004).

${ }_{78}$ Within the horizon of the imaginary, the facts lie at the same level of vision, which is neither imagination nor conception but rather a third afflicting plane, a phantasm. The technological recording of the real event depletes it of its content and transforms real violence into a fictional phantasmagoria. The miracle of special effects creates a mass doubt in the face of which common sense used to say: "But that's just a game!", which no longer works in our day and age.

M. Vitta, Il rifiuto degli dèi. Teoria delle belle arti industriali, Torino 2012, 6. 
enticing power of the aesthetic in the system of production and communication produces a generalization of the aesthetic categories and values (style, fashion, design, marketing, entertainment, cosmetics, creativity, culinary art, furnishing, etc.), not least through the technological acceleration of traditional means of expression (photography, cinema, new media, etc.).

The aestheticization of the lifeworld is currently not only a question within the realm of aesthetics but rather concerns a new order of the social world, that is, a new psychic economy as well as a new way of understanding the human experience. It therefore concerns not only our partial access to the artistic world but rather our general encounter with reality. Therefore, aestheticization is a fundamental phenomenon of our society, as is the secularization and technique to which it is strongly connected. "The aesthetic," says Perniola, "is the socio-anthropological dimension of the Western way of life". 80

It should be emphasized first of all that the aestheticization of the lifeworld strongly ties the latter to the "aesthetic economy"; namely, the domain of all products that are under the dominant influence of the new media. The market system appeals to the aesthetic sense, it relies on the enchantment and enthusiasm that surrounds its products, consumerism exploiting the mechanisms of lure and fascination, in other words, aesthetics. The market has become so strong and effective because the visions and dreams of globalized citizens are being increasingly entrusted to the narratives advertising commodities. The enchantment of the media world thus creates the dream of a new potential reality.

The phenomenon could be described as follows: the paradoxical event of the twentieth century is that the whole legacy of the Fine Arts has gone into the system of commodity production and mass communication. "Supermarkets are similar to museums," Andy Warhol once said. The commodities, the shops and the streets are the new places of the aesthetic. ${ }^{81}$ It is a continuous phenomenon that permeates all forms of our collective existence.

Last but not least, it transforms religious experience by providing aestheticization with a massively subjectivist component that promotes the search for identity, the anesthesia of collective life, and the liberation from individual

8o M. Perniola, Contro la comunicazione, Torino 2004, 64.

81 To use Lacan's terminology, art has lost its symbolic meaning and has fallen to the level of the imaginary. The classical artistic approaches were deconstructed in the 2oth and 21st centuries (by Lucio Fontana, Alberto Burri, but also Picasso), while the beauty of art was shifted to the field of production and communication (from Andy Warhol up to advertising). Camille Paglia writes: "[The Avantgarde] was killed by my idol, Andy Warhol, who included the most conspicuous commercial capitalist imaginary (like Campbell's soup can) that most artists had so far consistently spurned in his art". 
responsibility. This aestheticization dramatically expands into the political sphere, which has meanwhile made itself an object of representation, exposing the insecure masks of its own spectacle unrestrainedly to the civic and media scene. It concerns the "whole system of objects" as defined by Jean Baudrillard, namely, it permeates the products that define our social context. ${ }^{82}$

The dominance of "playing to the gallery" promotes an "aesthetic atmosphere" through design, cosmetics and advertising, which, according to Gernot Böhme ${ }^{83}$, creates a hybrid virtual and phantasmic universe that extends beyond all veractiy to all spheres of individual and collective life. Today, aesthetics equals an "access" to the world, which is a point of reference shared by all, insofar as it produces ideal beauty as a continuous enchantment of everyday life. This enchantment clearly expresses itself in the pursuit of self-realization, the optimization of enjoyment, the ever-increasing quest for physical well-being, the search for the product image and the "look", new developments in cooking and eating, the political cult of the personality etc.

Creativity is for selling, selling is for enjoyment, enjoyment is for prosperity. The ingenuity and the talent of enjoyment, which one might also call luck without content, express the power of thought that must be purposive in terms of psycho-physical well-being in the process of aestheticization.

The "fine art" of the humanist tradition and romantic aesthetics have at present massively broken out of their demarcated domain and transferred to the world of digital technology and the system of commercial products that make up the aesthetic "skin", i.e. which forms the omnipresent mediator of contemporary consciousness. As a result, a new aesthetic "dispositive" has emerged that distinguishes itself in all these technological and economic developments and replaces the high arts. The critic and theoretician Gillo Dorfles ${ }^{84}$ wrote in 1965:

82 "At the opening of the Holy Year, it was decided that Wojtila should wear a lurex coat because this synthetic fabric was more luminescent than the other materials and therefore more effective for television. So we are faced with a backdrop that has already planned reality." (G. Dorfles, Il feticcio quotidiano, Roma 2012, 7).

83 See G. Böhme, Aisthetik. Vorlesungen über Ästhetik als allgemeine Wahrnehmungslehre, Munich 2001.

84 G. Dorfles (born in Trieste in 1910, died 2013), critic and philosopher, professor of aesthetics at the University of Trieste and Milan and visiting professor at several American universities, is an outstanding figure in European culture. In 1948 he founded the MAC (Movimento per l'Arte Concreta). For further reading on this topic consult: Discorso tecnico delle arti, Nistri-Lischi 1952; Il divenire delle arti, Einaudi 1959; Nuovi Riti, nuovi miti, Einaudi 1965; Le oscillazioni del gusto, Skira 2004; Artificio e natura, Skira 2005. His most famous work may be: Il Kitsch. Antologia del cattivo gusto, 1968. 
It is wrong to continue to believe that "art" is only that which is worshiped in museums or in concert halls, while at the moment it is ... being broadcast by the media and produced by industrial systems. ${ }^{85}$

Nearly 50 years after this claim was made, the consumption of images has clearly become the core of the economic system. ${ }^{86}$ The quoted citation therefore has a prophetic meaning. It indicates a direction that should be pursued today. The current aestheticization of the lifeworld is linked to the mechanization of thinking and everyday life. Today, beauty is located in digital technology, in the videos and in the performance of the media industry. The nymphs or graces of Botticelli, the warmth of Dürer's living nature or Turner's landscape poetics are multiplied and repeated in fashion photo reports and in the reports of the contemporary "society of the spectacle" (Guy Debord).

In this context of aestheticization, even Bosch's nightmares or Dalís surrealistic distortions transform into the special effects of science fiction films, video games and advertisements. Although art works seem to lose their "aura" in the age of technical reproducibility (Benjamin), digital culture reproduces the same aura in a strong collective enchanting effect. Roberto Diodato writes:

Today the categories of modern aesthetics, the concepts of beauty, taste, genius, originality, creativity, and feeling, are introduced with extraordinary social effects: they are the soul of the economic of the so-called advanced Western world ... of post-industrial capitalism; they are the laws governing the behavior of our common home. ${ }^{87}$

In his book Il feticcio quotidiano (The Daily Fetish) Gillo Dorfles examines the new tendencies of contemporary Western sensuality or the rituals, practice and changes in the use of symbols and the rapid change of taste (e.g in fashion trends) that modify our aesthetic perception. He claims that our socalled rational, secularized and enlightened society is still shaped by mythical undercurrents: "The veneration for the singer Madonna instead of the religious figure" - Dorfles writes - "is of course a form of idolatry". ${ }^{88}$ This represents a dangerous (post-modern) use of symbols and myths. For while symbols have always structured the social bonds of the community, the new idols serve the subject's timeless narcissistic aspirations for self-realization.

85 G. Dorfles, Il consumo delle immagini e la comunicazione artistica, in: G. Dorfles, Arte e comunicazione. Comunicazione e struttura nell'analisi di alcuni linguaggi artistici, Milano 2009, 10.

86 F. Carmagnola, Il consumo delle immagini, Milano 2006, 95.

87 Diodato, Il futuro anteriore dell'estetica, in: L. Russo (ed.), Dopo l'estetica, Palermo 2010, 93.

88 Dorfles, Il feticcio quotidiano, 15 . 
The key words of this configuration are the dominance of the surface, the excess, the meaning of the scene. Victor, the protagonist of Glamorama (1999) by Bret Easton Ellis, follows the motto: "The surface is a promise". ${ }^{89}$ His life is a display of surfaces and a sum of missed opportunities. In the novel, one encounters great metaphors of the mercantile and immaterial heart of the contemporary world, starting from the blending of reality and Reality Show to the confusion of roles and identities, from the subject of the doppelgänger to the fascination of ambiguity.

This fictionality represents the possibility to invent and communicate experiences and achievements that stand beyond the dichotomy of false-true, apparence-being, subject-object, surface-depth. It is important that these services participate in economic value processes. Fulvio Carmagnola writes:

The aesthetic appearance of the commodity is the place of manifestation of an oxymoron, a relation of opposites that would have been impossible at the enlightened and romantic modern age: the false, he appearance, the body, surface, glamor are signs of themselves and of what is true. ${ }^{90}$

The hypothesis here is that the symbolic order, namely the world of symbols, values, principles, meaning, the written and unwritten laws of our collective life, has become an image and the imaginary, and in this form constitutes the aesthetic element of our economy. "Today, most of creativity is focused on marketing products rather than products themselves, be they sports, shoes, or feature films". ${ }^{91}$ Therefore, our current economic form can be described as fictional and imaginary. ${ }^{92}$

Production - consumption - media communication: these are the main features of the new political economy of aesthetic phenomena. Mario Perniola asserts that "this tendency absorbs aesthetic instances by de-constructing the world of work ... In this way creativity is promoted at all levels and one gets

89 "Surface is a promise" was also the billboard advertising by the Volkswagen Group at the Frankfurt Motor Show in 2003. This ingenious advertising shows just how real the aesthetization of the lifeworld is and how it shapes our thoughts and feelings. "Innovation is the search for the shape of tomorrow. The surface is not only a technological apparatus, but also a glimpse of the future and an anthropological vision. Functionality lies in man's nature." See Carmagnola, Il consumo delle immagini, 131-133.

$90 \quad$ Carmagnola, Il consumo delle immagini, 8.

91 W. Gibson, Laccademia dei sogni, Milano 2005, 74.

92 See R. Diodato, Marketing, o dell'esperienza estetizzata, in: P. Pellegrino (ed.). Estetica \& Marketing, Lecce 2010, 31-36. 
the impression of participating in an exciting and avant-garde act. The creative manager represents the heir to bohemian artists. ${ }^{93}$

This expresses itself in the twofold movement of the commercialization of the aesthetic and the aestheticization of the world of commodities, in the indifferent praise of diverse lifestyles or status symbols. The economy is aesthetic insofar as it produces goods whose appearance is decisive for their value, and which produces pleasure, or rather enjoyment. In any case, it seems that beauty has become simultaneously more widespread and weaker in this process of aestheticization. Its increasing dissemination through the world causes a growing melancholy feeling of emptiness.

\section{Law and Pleasure of the Word}

The problem is not primarily that the "great narratives" that could provide us with ideas to guide us have come to an end (according to Lyotard) but rather that post-industrial Western society is providing us with new great narratives. The Neo-Enlightenment epic of science and technology, the ideology of the neo-liberal market economy, and the neo-romantic epic of eros and prosperity.

The model of Western development is based on these three models of freedom and the will with which it tries to tell its history through digital language. The epic of the great narratives relocates to the short little media stories presented in commercials, talk shows, television series and the creativity of design and fashion, which still have a strong and influential effect.

It could be said that postmodernity is the end or crisis of the symbolic, or rather, that it represents the shift from the symbolic to the imaginary. In this shift, the experiences, narratives, meanings, discourses become "easier" and "weaker". They are without gravity. The symbols in premodern and modern communities had the crucial power to structure collective and shared reality through written and unwritten norms, rules, laws, rituals and myths.

Today's prevailing images are chaotic fragments of the imaginary that have disrupted their affiliation to the symbolic system of shared meanings and values. What is even more radical is the fundamental problem that the "epidemic of the imaginary" not only reflects itself in the "particles" of melancholy and confusion but also produces a monotony of excess, which leaves subjects without protection, without "garment of grace" and subject to the intolerable proximity of the real. Our age is referred to as the "age of fear," because transgression is made the norm by the absence of prohibition.

M. Perniola, Del sentire, Torino 2002, 65 . 
This lack leads us into the oppressive proximity of the object-cause of desire, the real of desire. We lack the space to breathe created by prohibition. Symbolic prohibition no longer works, because the unwritten rules of enjoyment are not considered "symbolic castration", through which the symbolic order is established, but as a regulation of transgression itself. The price for this lack of guilt is fear as the only emotion that does not mislead us. ${ }^{94}$ When the symbolic order wavers and its organization of the real decays, fear arises.

Without the protection of the symbolic, namely, of the "father" or of the "word" installed by him, the real becomes unbearable and fear remains as the only possible answer of the subject to reality or, in other words, to the destruction of reality now left without symbolic protection. Therefore, anxiety does not represent a situation of separation from but rather to the excessive presence of the real.

If symbolic efficiency is suspended, then the imaginary falls into the real: ${ }^{95}$ This means that what is repressed through the symbolic returns in a hallucinatory form, so that the connection between the imaginary and the real becomes threatening. It produces a grinning and ghostly double of traditional authority - Hitchcock and Lynch are masters of depicting it - super-egoist and cruel characters that replace the lack of the prohibition of the symbolic order.

The crisis of the symbolic order is a crisis of the law of the word, i.e. the absence of the words that shape the instincts, humanize their chaotic and speechless core, and thus allow them to distance themselves from their aggressive aberrations. This often only leaves violence. For desire is capable of orienting and structuring existence around its inexhaustible mystery by inserting it into language. Life becomes humanized thanks to the blessing of the word of the Other.

Lacan thus remains in a horizon already outlined by Hegel in the Phenomenology of Spirit, showing that humanity demands to be recognized in the particular value of the Other. The value of my word depends on the Other hearing it, and the word becomes meaningful only when the Other answers it. There is no word for Lacan that finds its fulfillment without the Other:

Now all speech calls for a response. I will show that there is no speech without a response, even if speech meets only with silence, provided it has an auditor, and this is the heart of its function in analysis. ${ }^{96}$

94 "Anxiety is that which does not deceive" (J. Lacan, The Seminar, Book XI, 41).

95 See S. Žižek, The Ticklish Subject. The Absent Centre of Political Ontology, New York 1999, 369-377.

96 J. Lacan, Écrits, 206. 
Herein lies the dialectical dimension of the word, which finds its realization only through its being heard by the Other. In a similar sense, M. Recalcati writes: "No word is merely the word of the subject, since its structure constitutively involves the Other, the answer of the Other, the response of the human community in which the dialectic of recognition actually takes place."97

The word addresses itself to the place of the Other, so that the discourse gains its meaning in a retroactive temporality, après coup. The one who speaks never really knows what he is saying, because he sends to the one who listens a message that only completes itself in the moment when the Other answers, the Other in turn sending the message retroactively.

In Lacan's Rome lecture of 1953, one can read: "Human language would then constitute a kind of communication in which the sender receives his own message back from the receiver in an inverted form." ${ }^{\prime 98}$ The dynamic of the word opens itself up to another conception of time, not composed of positive sequences that follow a deterministic chronology. For the future as retroaction (Nachträglichkeit) and as anteriority (après coup) means that the event of the past only gains meaning in relation to the event of the contingent word. This makes it necessary to undertake a retroactive signification of the past, because the past can only become history if it historicizes the present, if it touches on the word by calling on the Other regarding the future of its listening.

What is realized in my history is neither the past definite as what was, since it is no more, nor even the perfect as what has been in what I am, but the future anterior as what I will have been, given what I am in the process of becoming. ${ }^{99}$

The process of subjectivation is always a resumption, or better said, a recording of the past, of what has been, towards a future of what is not yet. So it is about an arrival as an open opportunity to give our own story an ever-new meaning. The subject of the unconscious is the place of a constant re-admission of what has arrived, in a creative and continuous subjectivation of the already existing. It is a fragile and contingent process, but it has all the necessary power to change the course of our lives.

Sometimes a positive symbolization of the "already existing" is enough for the resurrection of the subject to happen. Likewise, it is sometimes enough for someone to speak your name or listen to your word, for the discourse, whose entire existence was left interrupted to become a possible narrative of the present, opening up new possible horizons of meaning within history.

97 M. Recalcati, Jacques Lacan, 78.

98 J. Lacan, Écrits, 246.

99 Ibid, 247. 
In a time shaped by the aestheticization of the world, with its digital imaginary, any temporal codex, historical hypothesis, or symbolic texture seems to dissolve into indeterminacy. The discourses dissolve into images, into an uninterrupted repeatability of their flow. Logos and logo are exchanged. The symbol becomes the logo, the brand and its "narrative", that is, advertising, the new (short) description of the postmodern, which must keep desire alive. ${ }^{100}$

This brings with it a new social constellation that transforms the temporal event of being into the imaginary flow of appearance. This means that the editing of the "commercial" and the blog infects every other possible way of storytelling by inventing a new syntax and rhetoric. Even classic narrative content in the dramas or comedies on television and cinema are interrupted by advertisements, so suddenly the symbolic falls into the imaginary and we are brought back to "reality". The "categorical imperative" of the postmodern digital and commercial ego is to break the symbolic power of the large, detailed and touching narratives in favor of one's own hedonistic search.

The contemporary subjects, especially young people, are enthusiastically immersed in this technological environment that first appears as industrial design - from the new Volkswagen to the iPhone - which gives them access to reality. But unlike classical artworks, as Camille Paglia notes, there is no spiritual dimension in them. Is that true? Although the following statement may appear very bold at first glance, I would like to point out that even the successful commercial naming of the iPhone product with the " $i$ " (ego) contains a strong reference to the configuration of the postmodern subject.

This subject circles around its "I" in the constant search for its (imaginary) identity, which regards the iPhone or iPod or iPad as a projection screen of its own self-reflection. This search for a subjective identity does not include an alterity or the necessary encounter with the real Other, who is the only one who can offer the subject true recognition beyond its narcissistic circling around its own self-realization.

The virtual objects simulate real relationships, human experiences, real feelings in the form of fictional objects. The virtual exchange of contacts and friendships, the permanent need to always stay connected, express these ways of the subject which requires at least one virtual icon (e.g. the Facebook logo, the emoticons) for actual reality. This partially explains the success of Apple: Apple products represent a special form and beauty, namely surprising touchability (touch screen), a huge memory (the post-modern and digital memory) and beautiful computer graphics - Steve Jobs once said that he owes his main inspiration to a calligraphy course.

100 See G. Dorfles, Nuovi riti, nuovi miti, Milano 2003. 
The Italian philosopher Maurizio Ferraris claims ${ }^{101}$ that computers, smartphones, tablets are by their very nature large storehouses in which all the contacts, the messages, the thoughts of our lives are kept. Even the things we have forgotten remain stored there as in a kind of unconscious.

For Ferraris this storage is a kind of supplement of the soul, a reserve soul. The traditional idea of the soul among the Greeks was that of a wax tablet in which speeches, feelings, reflections were imprinted. The iPad is the outer prosthesis of this inner panel, and it is man's most recent prosthesis - following archives, books, documents etc. - with which mankind tries to remedy the finiteness of its memory and, above all, its lives. As long as a bit of memory remains somewhere (even in the iPad), it still seems possible to preserve a bit of soul.

These media products try to recapture the spiritual experiences of life by using the elementary needs and feelings of the human being: friendship and liking (the "like" button), touching, hearing from other people etc. However, this results in a certain loss of spiritual etiquette, because on this level the subject cannot decode its intentionality, its real experience, its real desire. And the more the subject tries to communicate, to connect with the Other, the more it understands that this way of establishing contact with the world substantially falls short of the effective embodiment of affects and feelings. The shortening of the syntax and the sentence in digital language (Twitter, texting) may well precisely express this unconscious disappointment.

What corresponds to the commercial aestheticization of the world is the immanence of beauty in consumer products, whose seductive appearance inspires human desire. What is the task of philosophy and theology in view of the fact that philosophy has always thought about the beautiful, the pleasant and taste? The questions I would like to ask are the following: Why is something considered beautiful?

What does the shift from the angel of traditional painting to the angels of Fiorucci, from the oriental kilim carpet in Anatolia to the kilim carpet as an ethnic institution in Europe, or from Christ's cross to Madonna's necklace with a cross mean? But first and foremost the question is: How can aesthetics open up a new view of the beauty of human experience and of its symbolic nature within this present process of aestheticization, whose images and imaginative forces are in strong relation to the economic system?

101 M. Ferraris, Anima e iPad, Milano 2011. 


\section{Aesthetics and Rehabilitation of Time}

Today, the aestheticization of the lifeworld clearly expresses the fact that aesthetics plays a fundamental role in our interaction with the world. Therefore, the question of aesthetics should assume a fundamental anthropological and even ontological character in this context.

The paradox is that only a rehabilitation of aesthetics, namely, a new perception of reality and a living sensitivity regarding the meaning of life can redeem one-dimensional virtuality and the timeless nihilism of the aestheticization of our lifeworld and thus form a new humanism.

A vague appeal to the classical ideal of beauty can merely nourish the aestheticizing and playful "drive" that this appeal seeks to call into question. This "solution" does not seem to be able to face the most important question that the aestheticization of the lifeworld poses. It is therefore important to emphasize that it is no longer possible to strive for a pure ideal of beauty that does not know contradictions, failure, defeat. This abstract and ahistorical beauty has become unbearable in our time because it does not know singularity nor contingency and thus neither knows human experience. This kind of beauty, too, creates an aestheticization of life by bringing about an anesthetization of feeling.

The aesthetic judgment on the beautiful is always both a judgment of taste and a one of sense, in other words, it essentially expresses as specific purposiveness. Kant writes: "The judgment of taste is therefore not a cognitive judgment, hence not a logical one, but is rather aesthetic, by which is understood one whose determining ground cannot be other than subjective."102 But this subjective determining ground claims universal validity, inasmuch as the judgment of taste "ascribes the satisfaction in an object to everyone."103

Where can one experience, find or invent a new subjective universality today? I believe that the various present experiences that the subject makes in its imaginary current interaction with the world always lack something important, which is a real experience of time. In our world of digital media, what comes to light is the man's deep need to stay in touch, to live in a world shared amongst and with one other (the World Wide Web), and to relate (to each other), to communicate in a common language.

However, this virtual domain lacks a real aesthetics of time and the word. The rehabilitation of aesthetics in particular calls for the recovery of the temporal dimension of life through a deepening of the aesthetics of the word (instead

\footnotetext{
102 I. Kant, Critique of the Power of Judgment. Edited by Paul Guyer, Analytic of Aesthetic Judgment, § 1 The judgment of taste is aesthetic, Cambridge 200o, 89.

103 Ibid, 99 .
} 
of the image). It is about the taste for "grammar", the desire for connections, the interest in the distinction and the organization of reality, which can only be produced by narrativity. In order to create the connection between the particular and the general, the "time of narration" seems necessary today.

Today it also seems necessary to give the subjective experience of narrativity a new meaning and centrality. For Kant, the judgment of taste is also the effect of a particular view, an operation of the senses, which reaches from the particulate to the general without concept. The judgement of taste is looking for a rule, a law, because these rules and laws are not natural. One could also say that this aesthetic power of the judgment of taste, which can give meaning to life, can be realized through the discovery of the logic of time.

Following Lacan, one could say that past, present, future and memory are of linguistic nature. For Lacan, that means that the experience of temporality and its effects is an effect of language itself. Historical continuity depends on the acceptance of paternal authority, as Lacan says. In this sense he speaks of the "name of the father" as a linguistic (but ultimately as an ontological) function. When this master signifier breaks down, the human being is in danger of sliding into psychosis, in which even time no longer remains as an identity-structuring dimension. Schizophrenia is based on the failure to enter this symbolic order. It represents a collapse of language that brings with it a break in the experience of time. This means that only the logic of the narrative can unfold the meaning of experience and bring to light its (retroactive) truth.

In the configuration of our society, however, it is important to overcome the tendency to see image and word as merely contradicting one another. It thus seems necessary to give syntax a new meaning, or a new differentiated structure, namely, to arrive at an aesthetics of language and time, which, with the aesthetics of the image and space, realizes a kind of connection that may enable us to break out of the imaginary closed circle of virtual reality.

It is no coincidence that in contemporary art there is a return to graphs, to inscriptions, to words in pictures, which manifests itself as an enjoyment of the text, as the aesthetic enjoyment of a kind of readability of the world. It is a about positioning words in the picture, about the aesthetic search for an original semantics. Abstract art wanted to achieve this pure semantics by overcoming representations and shapes, in which words were only to remain as the titles of the works. But it has become increasingly clear that no signification emancipated from the signifier can exist without the meaning of a fundamental order, a basic syntax, that is, without a shared symbolic order, beyond the bad infinity of (digital) combinatorics.

Nowadays it seems that different contemporary artists (e.g. William Xerra, Johannes Zechner, Marco Nereo Rotelli, Hannes Priesch, Maurizio Nannucci, 
Leo Zogmayer, Werner Hofmeister, Fritz Ganser, Markus Wilfling, Helga Chibidziura, etc.) feel compelled to incorporate the insurmountable experience of the word into their own works in order to bring the effectiveness of Scripture back into play. The ways of the Kabbalah, as well as the artistically designed initials of the missal and the breviary represent the prehistory of this religious possibility of a combination of words and images, a new religious calligraphy in a way. It is about a new appearance of connections as the texture of signifiers capable of representing a new syntactic order.

While the images express the constant circulation of commodities, the narrative embodies the transmission of meaning. While the imaginary order of the "time of the imaginary" offers timeless objects, the gift of narrative founds the subject in its historical singularity (or subjective universality). The narrative generates new worlds but no interchangeable products, since it invents the meaning of the event and does not simply represent something useful.

This is a non-utilitarian purposiveness ("purposiveness without an end") as a critical instance regarding the current relocation of aesthetics in the market system of Western society.

In this context, what would be the significance of the syntax, which should not only be understood as a purely technical theory of grammar but as the linguistic comprehensibility and readability of the world? The function of the words is not only to depict something, but also to describe an experience that had. We need words, not only to make ourselves understandable to others, but also to make ourselves understandable to ourselves.

The role of the syntax is to elaborate and structure human experience reflexively within the time of the narrative. Thus, it represents not just an arrangement of words and sentences but also the order of affects and the logic of meaning. The purposiveness of the narrative does not consist in the production of a world, but in aesthetic reflexivity that finds meaning and introduces it to the subject, who clothes meaning in a sensual phenomenon.

The narrative could be the "second skin" of the subject, which can act as a protection against an aestheticizing form of nihilism. It is not about the pure reflexivity of the mind or reason but about a sensual reflexivity without concept, which has its own syntax and logic that represents time in a special way. It is about the past, the present and the future (and the past future) of life, which always needs a syntax. To paraphrase Kant: "Language must be able to accompany all my ideas".

In connection with the narrative, could one attempt to call this sensual reflexivity a "temporal spatiality"? - A "temporal spatiality" beyond the dualism of sensuality and reason, which not only gives art objects an "aura" but also reveals a higher purposiveness? The logical order of the narrative is not a static 
or abstract arrangement of events and words but a temporal development that does not take place against the background of a logic of the "space-image" but the "time-image". ${ }^{104}$ While sensuality achieves a particular temporality through narrative, this narrated sensory experience could represent the place of that particular universality where the subject could find a possible sign, a singular call, and some orientation for its life.

It is said that Kafka had the habit of taking a walk in the park with Dora Dymant from Steglitz to Berlin. One morning in the early summer of 1923, just a few months before his death, now withdrawn from the world because of his tuberculosis, he met a little girl who was desperate and completely distraught. This grabbed his attention and compassion. Kafka did not hesitate to approach her and ask her why she was sad. The girl named Elsi replied that she had lost her doll.

As a result, Kafka compassionately invented a story to ease the suffering of the loss. The doll, the writer said, was not lost but simply set out on a long journey to get to know the world. Kafka spontaneously replied to the girl's skeptical reaction that he had received a letter from her. The girl was convinced, and Kafka took care in creating the letter between the girl and doll with as much seriousness and creativity as possible. Every day in the park, his reading of each letter took place aloud and like a pact and encountered an astonished and attentive listener.

In her stories, the doll explained that it would have been necessary for her to experience new things, to get to know the world and to meet new people, without wanting to cause her friend, whom she had left behind in Berlin, pain. According to Dora's statement, Kafka had executed the scripts with the utmost care, in a lively and precise prose, in the alchemy of an encounter full of secrets that took place with reliable regularity for three weeks. The last letters were like an epilogue designed to gently prepare the girl to say goodbye to the moment when the doll would disappear forever from the girl's life without causing trauma. In fact, the final split did not produce any imbalance.

If an affliction is fortunate enough to be part of a story, it might lose its unfortunate power in order to participate in a common cause. It is not a merely imaginary and phantasmatic transformation but the power of the shared Word, which gives things their name by leading them out of the ominous burden of mute silence. The Law of the Word and the grace of the story give the feeling of life continuity and a horizon in a way that does not simply dissolve it in the fuzziness of the emotion but gives it the perspective of believable and understandable meaning.

104 See G. Deleuze, Cinema 1: The Movement Image: Cinema 1, London \& New York. 2002; idem., Cinema 2: The Time Image, London \& New York, 2005. 
This is possible because the narrative produces a spatiotemporal deferral, i.e. the necessary "displacement" which - as is the case with anamorphosis - reconfigures the experience beyond the illusion of a direct and frontal encounter with the events. The "technical mediator does not randomly aim for an immediate emphasis, for real time (i.e. the temporal zero-point of the simultaneity between action and reaction), replacing the infinite a-chronicle of the babble with narrative syntax". ${ }^{105}$

In contrast, the narrative gives the subject time to enter and exit stories, gaining a relaxed and patient look at one's own and other people's lives. The time of the narrative is like a "gown of grace", a "second skin" that protects and collects in its drama the scattered pieces of human desolation, freeing them from their fossilization and weaving them back into the time of care and proximity. The question that should be asked both in the stories and in analysis is the question of the effectiveness of the word. In analysis, it becomes increasingly clear that the word treats and that the body speaks. Lacan exemplifies this question in his interrupted seminar On the Names-of-the-Father:

The average person or man in the street does not seem terribly astonished by the effectiveness of this practice that occurs entirely through speech. And he is, in the end, quite right, for indeed it works, and it would seem that, in order to explain it, we need first but demonstrate its movement by working. To speak is already to go to the heart of psychoanalytic experience. Here it makes sense to first raise a question: What is speech? In other words, what are symbols? ${ }^{106}$

The significance of the word's effectiveness implies, but transcends, the performative meaning of language since it is a question of the possibility of the word and symbolization to save human life. This concerns not only the therapeutic process of analysis but also the significance of a divine revelation in words as it occurs in the Bible.

For centuries, the Bible represented the immense lexical, cultural and iconic wealth of the West. According to William Blake, the Old and the New Testament are "the great code of art"107. In his Mimesis (1946) ${ }^{108}$ Erich Auerbach acknowledges the Bible and the Odyssey as the defining models of our culture,

105 F. Stoppa, La restituzione, Milano 2011, 216. The Italian original says: "Il mediatore tecnologico, non per caso, mira ad enfatizzare l'immediatezza, il tempo reale (ossia il tempo zero della simultaneità fra azione e reazione), sostituendo l'infinita sequenza a-cronica di cinguettii alla sintassi del racconto".

106 J. Lacan, On the Names-of-the-Father, 7.

107 "Jesus and his apostles and disciples were all artists, and the Old and New Testaments are the great code of art."(W. Blake, Complete Writings. With Variant Readings, Oxford 1972, 777).

108 E. Auerbach, Mimesis. Represented Reality in Western Literature, Princeton 2003. 
and Northrop Frye looks at the Scriptures in his The Great Code, the Bible and Literature $(1981)^{109}$ as the universe in which Western literature and art operated up to the 18th Century and still operate.

The biblical word in its entirety can also be understood as the narrative of the word's efficacy in the people of Israel, as the place where various figures of the human experience make a potential everyday encounter with the "full word" that can bring about a real change in human life. In the biblical stories, in fact, the various embodiments, inscriptions, injuries, and imprints of the word onto the body of the believer are told, expressing ever-new locations of the symbolic.

Today it seems necessary to ask whether in this tradition Christianity can still be understood as a narrative of these incarnations of the word, in which the mortality and the vulnerability of the human can be discussed. As in Kafka's encounter with the doll, in which a childish pain could be treated by a charming correspondence, the "big code", namely, the Bible can be read as that religious and cultural depositum in which every wound, every yearning, every cry, every suffering quest for meaning and every word of discouragement can find a symbol, a narrative, a metaphor and a hospitable answer. It is a linguistic "seam" in which the special and contingent fractures and wounds can be sublated into a saving texture, illustrating the universal Humanum.

The works of the Italian artist Giovanni Bonaldi express a possible combination of images and words in which this effect of the sacred text manifests itself in its urgency and truth. They deal with the appearance of sacred manuscripts ${ }^{110}$, of mysterious letters as temporal tables of an alliance between Judaism and Christianity, as hospitable arks of the lost, fighting against disappearance and oblivion. The Torah is portrayed by the artist as a shrine or chalice, capable of receiving human injuries and incisions.

To show this possibility on the threshold of images and words, object and subject, I would like to refer to another artist, Emilio Isgrò, who invented the "Theory of Over Coating". He developed his poetics in Milan and Venice, which abolishes any redundancy while (almost) protecting a fragment of the miracle of the word. In his paintings, he does not produce cuts in the canvas (like Lucio Fontana), but crossing out words.

This not only means that a (crossed-out) language should be received in the images. By erasing, Isgrò rather wants to show that language has almost gone into what is foreign to it but that there still remains something of it. "There is a

\footnotetext{
109 N. Frye, The Big Code. The Bible and Literature, Toronto / Buffalo / London 2006.

110 G. Bonaldi, Lorigine tesa - The Tension of Origin, Milano 2003; G. Bonaldi, L'ospitalità dell'Arca, Milano 2006.
} 
time to cross out words and there is a time to regain them," the artist writes in his book La cancellatura e altre soluzioni. ${ }^{111}$ This erasure thus does not intend to reject the word but rather to unearth its lost dimensions beyond any artificial "special effect".

Without suppressing the despondency, the fears and the suffering, it knows how to inscribe them into a wonderful texture, in which the imaginary, the symbolic and the real seem to unite in a precarious and wonderful equilibrium and the variations of the pulsating common human shine, if only for the contingent act of reading. These are indeed "narratives of tangibility"112 that generate those joyful encounters that, as Spinoza said, reveal the meaning of the whole and life in the intensity of a momentary and fleeting vision.

They are like those "moonbeams by sunlight" (Musil), which spread over what is most sensitive and precarious and illuminate the invisible interweaving of the fabric of the world. It is not for nothing that Spinoza defines this "being seized" as amor Dei intellectualis, which is able to understand the natural connection of modes and attributes, which translates into an affective relationship with what exists. In the uncertain time of the aestheticization of the world, that is, in the contingency and inconsistency of temporal shapes, which offer no ultimate meaning, the "this face was transfigured, becoming peaceful, deceptively beautiful, and radiant, by a single thought! For what if it were God Himself who was devaluing the world? Would it not then again suddenly acquire meaning and desire? And would $\mathrm{He}$ not be forced to devalue it, if $\mathrm{He}$ were to come closer to it by the tiniest step? And would not perceiving even the anticipatory shadow of this already be the one real adventure?"113

The reciprocal gift of the narratives could (precisely because of their "untimeliness") represent a contemporary subjective experience of the "sad affects" in the post-secular epoch and introduce them into it. This aesthetic "invention of the ordinary" or "practice of everyday life", which is narrative, could be an opportunity to overcome today's aestheticization of the lifeworld. It represents an attempt to find narrative antibodies against the "excessive minimalism" of digital communication in order to free oneself from the atemporal and a-syntactic placenta of images for experiencing a new, shared historical linguisticity.

\footnotetext{
111 E. Isgrò, La cancellatura e altre soluzioni, Milano 2007, 78.

112 K. Appel, Christianity as a New Humanism. Second Transition - From the Contingency of Existence to the Body of God, 27.

113 R. Musil, The Man Without Qualities II. From the Posthumous Papers, Translated by Burton Pike, New York 1961, 162-163.
} 


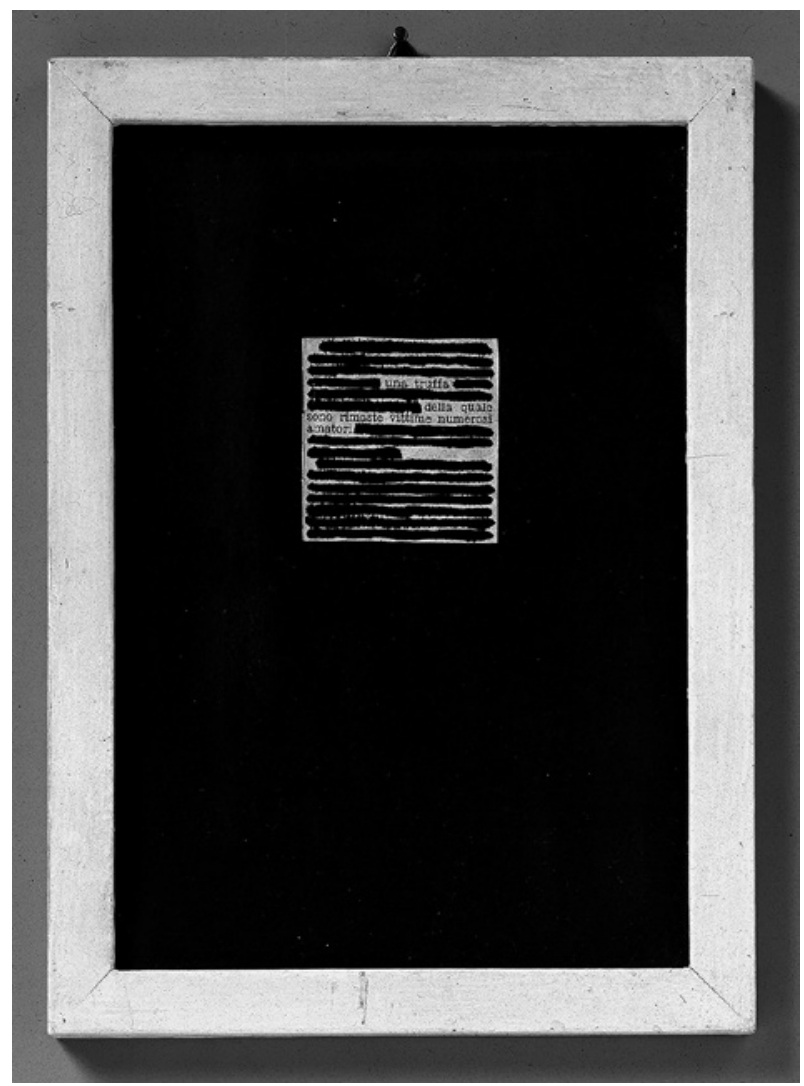

Fig. 3.1 Emilio Isgrò, Cancellatura (Erasure), $22 \times 16 \mathrm{~cm}$, Chinese ink on newspaper on a light cardboard box, Private Collection, Milan, 1964. 


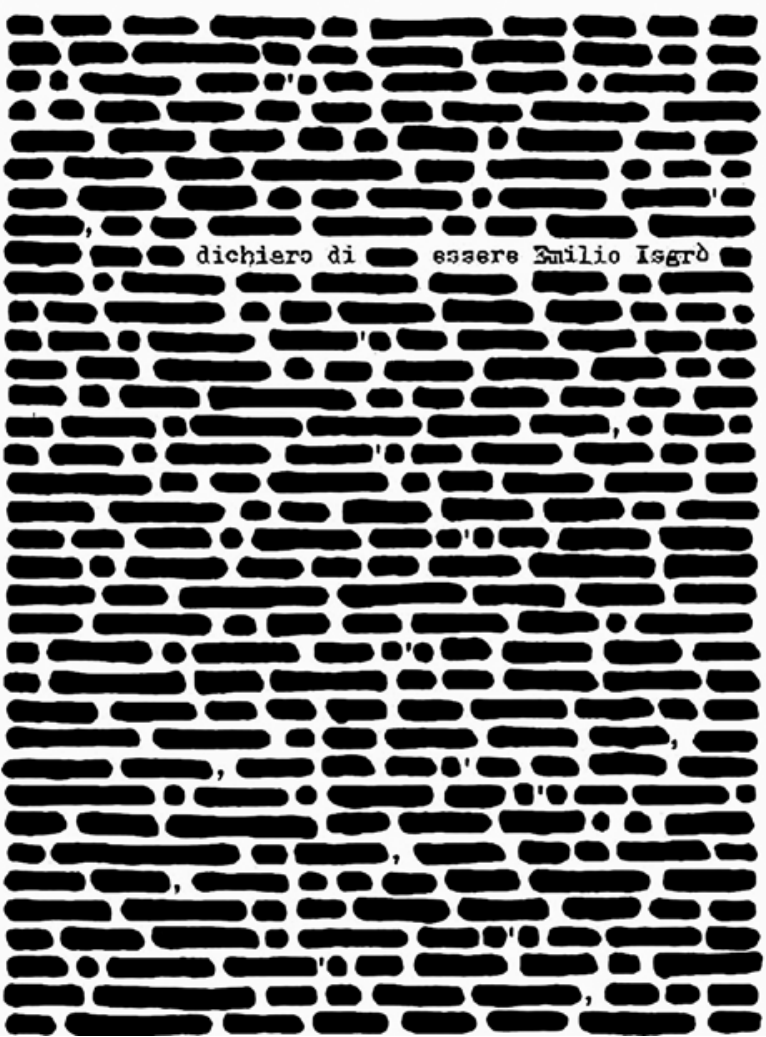

Fig. 3.2 Emilio Isgrò, Dichiaro di essere Emilio Isgrò (I declare that I am Emilio Isgrò), $400 \times 287 \mathrm{~cm}$, Acrylic on canvas mounted on wood, Collection Centro per l'Arte Contemporanea Luigi Pecci, Prato, 2008. 


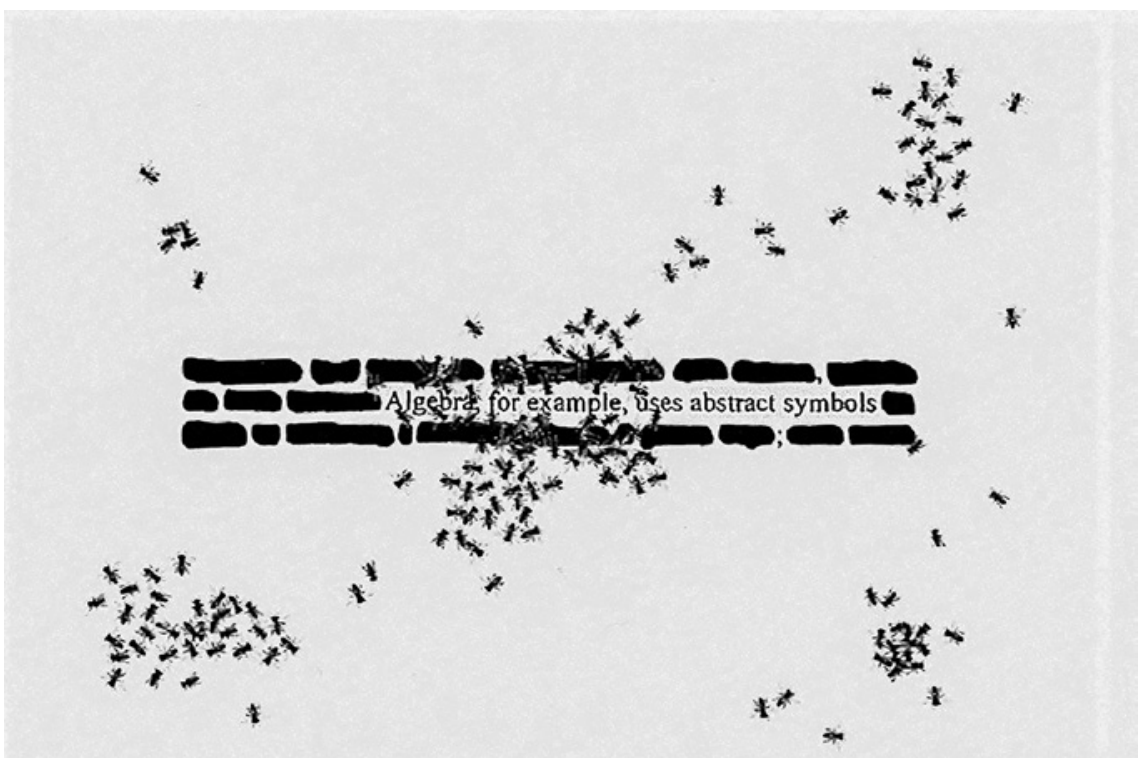

Fig. 3.3 Emilio Isgrò, Algebra, $70 \times 100 \mathrm{~cm}$, Acrylic on canvas mounted on wood, Private Collection, Milan, 2010. 